\title{
Effects of a mechanical engineering design course on students' motivational features
}

International Journal of Mechanical Engineering Education 2015, Vol. 43(I) 44-74 (C) The Author(s) 2015 Reprints and permissions: sagepub.com/journalsPermissions.nav DOI: 10.1I77/03064I901558I734 ijj.sagepub.com ๑SAGE

\author{
Zahed Siddique', Patricia L Hardré ${ }^{2}$ and \\ Defne Altan'
}

\begin{abstract}
Diverse learning opportunities and deep engagement are needed to support development of engineering competencies and expertise. Deep engagement evolves from productive and high-quality motivation that derives from both internal and external sources. Motivation to learn is lacking in many fields, like engineering, because it is too often assumed or ignored, rather than explicitly built into course instruction. While the lack of motivation in engineering education is clear in data-like attrition, there is little relevant research that informs the necessary changes for the field. The purpose of this study is to present a systematic approach that explicitly considers motivational elements in engineering courses. First a comprehensive set of motivational characteristics and the interrelationships for productive motivation of mechanical engineering students are identified. Students' motivational characteristics and profiles of change over time are assessed using a multipoint predictive correlational design. This information is then used to strategically redesign motivational elements of a senior-level mechanical engineering design course. The SUCCESS framework has been used to redesign motivational features of the existing course. This paper reports results of the study, including implications for redesign of other engineering courses. Analysis of the data demonstrates the complexity of motivation in the engineering classroom, which includes addressing implicit and explicit, intrinsic and extrinsic, individual and team interaction and instruction. These elements extend not only to direct communication and interactions of instructor with students but into the full scope of the learning environment, peer-to-peer interactions, grading, (a)synchronous activities, face to face, and virtual communications. Key features of engineering students' productive (learning and engagement-related) motivational profiles consisted of clusters of perceptual and
\end{abstract}

\footnotetext{
'School of Aerospace and Mechanical Engineering, University of Oklahoma, Norman, USA

${ }^{2}$ Department of Educational Psychology, University of Oklahoma, Norman, USA

Corresponding author:

Zahed Siddique, School of Aerospace and Mechanical Engineering, University of Oklahoma, 865 Asp Ave, Norman, OK 73019, USA.

Email: zsiddique@ou.edu
} 
experiential variables that were strongly correlated with motivational and learning outcomes. Tracking these factors demonstrated that they changed over time. These changes corresponded to perceptions of instructor and peer interactions, which were amenable to instructional intervention and responsive to social modeling. This study also revealed links among engineering students' perceptions of their field of study, their own development of self-efficacy, and success expectations in both the design course and for their careers. This work revealed important distinctions between engineering students' self-efficacy for, and engagement in, the course generally and for group tasks more specifically. These newly revealed relationships offer the opportunity to improve engineering instruction and the design of dynamic learning environments that support adaptive skill development.

\section{Keywords}

Motivational design, engineering education, engineering design course

\section{Motivation in engineering}

Education is never only cognitive, informational, or rational in nature, because teaching and learning include motivation. ${ }^{1-3}$ Learning activities exist within complex learning environments, ${ }^{4}$ which can be enhanced by designing with explicit attention to their motivational features. ${ }^{1,5}$ This attention is particularly critical in fields, such as engineering, with historically lower motivation and existing skill gaps. ${ }^{2}$

The United States faces an unprecedented shortage of talented professionals in applied technical design fields such as engineering, ${ }^{6,7}$ and the alignment of engineering curricula with actual demands in the field is in question. ${ }^{8}$ In addition, high attrition and demotivation in US engineering education have resulted in a shortage of well-prepared next-generation engineers. ${ }^{9,10}$ Both course and program completion run low for engineering programs overall. ${ }^{1-16}$ Attrition is high, yet less than $10 \%$ of students leave due to low grades or failure, ${ }^{17}$ indicating that this decrease in the number of students is due to other factors, such as motivation.

Engineering educators and instructional designers need to understand the motivational dynamic of attrition and the potential of motivational enhancement to address shortages and quality gaps in engineering. In this paper, a comprehensive set of motivational characteristics are used to develop a motivational profile of students in a mechanical engineering (ME) design course. This paper presents an approach for mapping and redesign of ME design course activities using the SUCCESS framework for motivation to support competency development. A comprehensive set of measures are used to assess motivational characteristics of students. Motivational changes over the semester are evaluated to understand the influence of the design course on student motivation in engineering. The SUCCESS framework is presented in "The SUCCESS framework: Strategic tool for motivation integration" section, followed by the experimental design approach 
and method presented in the following section. Results of the study and discussion are presented in the subsequent sections, respectively.

\section{Motivational characteristics for engineering students}

A number of motivational characteristics generalize well across disciplines, to promote learning and transfer to professional practice. Some of these characteristics have been highlighted in the limited existing motivational research in engineering. Personal motivational characteristics demonstrated as functionally positive and important for engineering education include: interest, ${ }^{18}$ positive task outcome expectancies, ${ }^{18,19}$ and expectancy for success in engineering. ${ }^{13}$ In engineering, as in other fields, various forms of efficacy support learning and performance, particularly in the face of challenges: general self-efficacy, ${ }^{20}$ engineering self-efficacy, ${ }^{13}$ and coping efficacy. ${ }^{21}$ A motivational factor reducing learning and performance in engineering education is performance anxiety. ${ }^{19}$ Perceptual field and content-specific factors supporting success include: engineering intrinsic interest value, attainment value and extrinsic utility value, identification with engineering, engineering achievement, and engineering career plans. ${ }^{13}$ Major choice goals (i.e. how long a student intends to remain in engineering) also influence motivation to learn in the short term. ${ }^{18}$ One study demonstrated that engineering students' expectancy- and value-related beliefs may decrease over the first year of study. ${ }^{13}$

Learning climates of design courses need to motivate and engage students to be resourceful and genuinely interested in the course material, collaborate with peers, and interact with instructors inside and outside of class. ${ }^{22}$ Strategies to promote self-efficacy in engineering need to integrate mastery experiences, and the identification of valued skills, conveying the importance of skills to learners, and provide vicarious success experiences with verbal encouragement. ${ }^{20,23}$ Engaging course climates for engineering courses are dependent on instructor accessibility and openness to student questions, use of appropriate technologies to illustrate concepts, and teaching strategies that offer immediate feedback. ${ }^{24}$ These studies have illustrated motivational characteristics important to engineering education, but few research studies have operationalized specific strategies to promote productive motivation in engineering design courses.

Engineering requires both advanced technical skills and creative elements of expertise, like other scholarly and applied design professions. ${ }^{25,26}$ Historically engineering graduates lack critical professional skills and meta-skills (e.g. critical thinking, problem-solving, communication, and teamwork). ${ }^{27-32}$ Next-generation engineers need skills adaptive enough to address changing needs ${ }^{33,34}$ and innovative enough to address unforeseen challenges, ${ }^{6}$ including the highest possible level of meta-competencies. ${ }^{35-39}$ Consistent engagement in higher level cognitive activities (e.g. analysis, synthesis, and evaluation) leading to adaptive design expertise requires more than following new rote processes or procedures. Engineering learners need to develop higher order habits of mind. ${ }^{40-43}$ 
In such an effort, it is important to recognize the nature and complexity of motivation. It is nonlinear, and optimal motivation is not as simple as highest scores on a set of motivational characteristics linked to success. Many studies in education have demonstrated that an optimal motivational profile includes the complex interactions of multiple motivational factors, both personal and environmental. ${ }^{44}$ Recent studies in applied design skills outside of engineering have further shown that motivation for maximum learning often includes readjustment (a "reality check") and reconfiguration of factors to support growth and expertise development. ${ }^{45,46}$ For example, for teachers from other disciplines learning engineering for the first time, motivational adaptation to support development demonstrated similar patterns, including an early downward trend in some perceptions, followed by recovery and reconfiguration. ${ }^{47}$

A common assumption of project-based course design is that projects themselves are motivating. ${ }^{7}$ Active learning (hands-on and project-based learning) is generally more motivating and engaging than passive learning (such as by lecture and reading alone). ${ }^{48-50}$ However, the nature and goals of any given project may be more motivating (e.g. more interesting, important, and engaging) for some learners than others, based on their values, priorities, and prior experiences. ${ }^{51-53}$ Thus, for different learners, different designs and environments for project-based learning can have very different motivational effects. ${ }^{1}$ Effective educational projects for engineering are not simple and neatly defined but are more often ill-defined, without "right" or absolute answers, amenable to a range of possible solutions. ${ }^{54-56}$ This paper focused on motivational characteristics demonstrated to support productive development of both technical skills and meta-competencies, because both are prerequisite to expert problem-solving.

\section{The SUCCESS framework: Strategic tool for motivation integration}

Within learning environments, every item of information, activity, appearance by an instructor, and assessment has motivational potential. ${ }^{56}$ If they are not proactively designed to be positively motivating, any of these features may present implicitly negative motivational consequences. ${ }^{57}$ Motivation is a rich and complex area of research and practice, informed by myriad theories, subfields, and perspectives, and its very richness can leave educators and course designers confused. ${ }^{56}$ The SUCCESS framework of motivating opportunities for instructional design is a tool for systematically integrating an array of useful, theoretically based motivating principles into any instruction. ${ }^{57,58}$ The seven-part framework provides structure for applying the principles, and the SUCCESS mnemonic cues application across all aspects of instruction (Table 1). It can be used to identify existing motivating elements of instruction and support optimizing potentials of instruction to fill gaps. Table 1 shows the key components of the SUCCESS model (far left), defines and operationalizes each component (middle column), and illustrates motivating strategies for each component in the design course being studied (right column). 
Table I. Using the SUCCESS framework to enhance motivational features in mechanical engineering design.

\begin{tabular}{|c|c|c|}
\hline SUCCESS Component & $\begin{array}{l}\text { Definition and } \\
\text { Operationalization of } \\
\text { SUCCESS Component }\end{array}$ & $\begin{array}{l}\text { Motivating Strategies for } \\
\text { Engineering Design } \\
\text { Using Each Component }\end{array}$ \\
\hline $\begin{array}{l}\text { SI: }_{1} \text { Situational } \\
\text { (Contextual and } \\
\text { Access issues) }\end{array}$ & $\begin{array}{l}\text { Focuses on nature of learning } \\
\text { and performance contexts, } \\
\text { autonomy support, authenti- } \\
\text { city, access, and control } \\
\text { (actual and perceived). } \\
\text { Learners provided with } \\
\text { motivationally positive situ- } \\
\text { ational features (choice about } \\
\text { how they do tasks) and with } \\
\text { access to support resources } \\
\text { engage and fit instruction to } \\
\text { their needs. }\end{array}$ & $\begin{array}{l}\text { I. Open-ended problem-sol- } \\
\text { ving tasks support auton- } \\
\text { omy and authenticity. } \\
\text { 2. Some requirements for } \\
\text { the project are set by stu- } \\
\text { dents for their solutions to } \\
\text { support autonomy and } \\
\text { independence. } \\
\text { 3. Students set their own } \\
\text { steps and plan projects, } \\
\text { based on design process } \\
\text { phases. These are profes- } \\
\text { sionally authentic } \\
\text { opportunities. }\end{array}$ \\
\hline $\begin{array}{l}\text { U: Utilization (Use } \\
\text { and Transfer Issues) }\end{array}$ & $\begin{array}{l}\text { Focuses on facilitating transfer by } \\
\text { bridging relevance gap from } \\
\text { instruction to application. } \\
\text { Utilization-focused motiv- } \\
\text { ational features of instruction } \\
\text { connect learning and transfer. } \\
\text { Instruction needs to address } \\
\text { how learners recognize their } \\
\text { need for instruction and see } \\
\text { themselves using it, both } \\
\text { during instruction and later. }\end{array}$ & $\begin{array}{l}\text { I. Lectures provide materials } \\
\text { linked to design of devices } \\
\text { and systems for near } \\
\text { future relevance. } \\
\text { 2. Learners utilize steps to } \\
\text { solve a design problem to } \\
\text { experience the relevance } \\
\text { of skills in their profession. } \\
\text { 3. Use of engineering tools } \\
\text { (CAD, FEA, CFD) relevant } \\
\text { to the profession. }\end{array}$ \\
\hline $\begin{array}{c}\mathbf{C}_{1} \text { : Competence } \\
\text { (Considerations } \\
\text { Focused on } \\
\text { Expertise } \\
\text { Development) }\end{array}$ & $\begin{array}{l}\text { Focuses on motivational consid- } \\
\text { erations related to current } \\
\text { competence development and } \\
\text { future, continuing expertise } \\
\text { development in the field. } \\
\text { Competence includes both } \\
\text { actual and perceived target } \\
\text { standards. They can be nor- } \\
\text { mative (comparing to others) } \\
\text { or criterion based (comparing } \\
\text { to established standards). }\end{array}$ & $\begin{array}{l}\text { I. Use professional compe- } \\
\text { tencies as implicit scaffolds } \\
\text { and rationales to justify } \\
\text { design demands. This sup- } \\
\text { ports students' clear, } \\
\text { credible expectations of } \\
\text { expertise targets. } \\
\text { 2. Students evaluate their } \\
\text { own and teams' compe- } \\
\text { tencies, along with setting } \\
\text { goals to develop skills, in } \\
\text { order to develop defin- } \\
\text { itions and vision for pro- } \\
\text { fessional expertise. }\end{array}$ \\
\hline
\end{tabular}


Table I. Continued

\begin{tabular}{|c|c|c|}
\hline SUCCESS Component & $\begin{array}{l}\text { Definition and } \\
\text { Operationalization of } \\
\text { SUCCESS Component }\end{array}$ & $\begin{array}{l}\text { Motivating Strategies for } \\
\text { Engineering Design } \\
\text { Using Each Component }\end{array}$ \\
\hline $\begin{array}{l}\mathbf{C}_{2} \text { : Content } \\
\text { (Knowledge and } \\
\text { Information } \\
\text { Components) }\end{array}$ & $\begin{array}{l}\text { Focuses on motivational elem- } \\
\text { ents of information provided } \\
\text { and supported through } \\
\text { instruction and needed for } \\
\text { performance. Consider how } \\
\text { information is communicated, } \\
\text { how it is supported, and what } \\
\text { is emphasized (explicitly or } \\
\text { implicitly) about it. Content } \\
\text { features are the most familiar } \\
\text { to most instructors, but their } \\
\text { motivational components are } \\
\text { often neglected. }\end{array}$ & $\begin{array}{l}\text { I. Students use materials } \\
\text { from previous engineering } \\
\text { courses, to analyze com- } \\
\text { ponents and develop pro- } \\
\text { ject devices. } \\
\text { 2. Prototype test provides } \\
\text { students with feedback on } \\
\text { their design process, sup- } \\
\text { porting evaluation of con- } \\
\text { tent knowledge and its } \\
\text { utility. } \\
\text { 3. Use students' content } \\
\text { knowledge to support } \\
\text { relevance perceptions, } \\
\text { linking current instruc- } \\
\text { tional demands to past } \\
\text { design courses and } \\
\text { experiences. }\end{array}$ \\
\hline $\begin{array}{l}\text { E: Emotional } \\
\text { (Affective and } \\
\text { Personal Issues) }\end{array}$ & $\begin{array}{l}\text { Focuses on personal, perceptual } \\
\text { factors with motivational } \\
\text { implications for instructional } \\
\text { effectiveness. Emotional issues } \\
\text { in motivation include thoughts } \\
\text { about the job, knowledge, and } \\
\text { skills that create positive or } \\
\text { negative emotions and states } \\
\text { (hope, optimism, anxiety, fear, } \\
\text { curiosity, hopelessness). } \\
\text { Emotions drive effort, risk } \\
\text { taking, innovation, and } \\
\text { honesty. }\end{array}$ & $\begin{array}{l}\text { I. The project and the com- } \\
\text { petition present anxiety } \\
\text { and frustration for stu- } \\
\text { dents, an authentic part of } \\
\text { the design process. If they } \\
\text { resolve ego issues, this is } \\
\text { stimulating and productive. } \\
\text { 2. Students observe per- } \\
\text { formance of their device, } \\
\text { which informs their com- } \\
\text { petence and provides suc- } \\
\text { cess experiences, or } \\
\text { recognition of need to } \\
\text { remediate. } \\
\text { 3. Students design and build } \\
\text { the prototype, so they } \\
\text { own the project and } \\
\text { products, promoting inde- } \\
\text { pendence and } \\
\text { empowerment. }\end{array}$ \\
\hline $\begin{array}{l}\mathbf{S}_{\mathbf{2}}: \text { Social (Group and } \\
\text { Interpersonal } \\
\text { Interactions, } \\
\text { Relationships) }\end{array}$ & $\begin{array}{l}\text { Focuses on motivational effects } \\
\text { of social and interpersonal } \\
\text { elements of instruction. These } \\
\text { include how groups learn and }\end{array}$ & $\begin{array}{l}\text { I. Students work in teams, } \\
\text { enabling social support, } \\
\text { sharing of expertise, and } \\
\text { encouragement. }\end{array}$ \\
\hline
\end{tabular}


Table I. Continued

\begin{tabular}{|c|c|c|}
\hline SUCCESS Component & $\begin{array}{l}\text { Definition and } \\
\text { Operationalization of } \\
\text { SUCCESS Component }\end{array}$ & $\begin{array}{l}\text { Motivating Strategies for } \\
\text { Engineering Design } \\
\text { Using Each Component }\end{array}$ \\
\hline & $\begin{array}{l}\text { work together, how they } \\
\text { communicate, and how they } \\
\text { interact with teacher-trainers } \\
\text { and systems. Social environ- } \\
\text { ment considerations influence } \\
\text { learning and performance. }\end{array}$ & $\begin{array}{l}\text { 2. Teams have high degrees } \\
\text { of shared knowledge and } \\
\text { skill (supporting common } \\
\text { discourse and effort), pro- } \\
\text { moting healthy teamwork. } \\
\text { 3. Members bring some } \\
\text { unique expertise, promot- } \\
\text { ing recognition and value } \\
\text { of individual skills, and } \\
\text { insights gained through } \\
\text { differences. }\end{array}$ \\
\hline $\begin{array}{l}\text { S }_{3} \text { : Systemic } \\
\text { (Organizational and } \\
\text { Systems } \\
\text { Considerations that } \\
\text { Facilitate } \\
\text { Performance } \\
\text { Improvement) }\end{array}$ & $\begin{array}{l}\text { Focuses on motivationally rele- } \\
\text { vant elements of instruction, } \\
\text { related to the system and } \\
\text { organization in which it exists } \\
\text { and for which it occurs. } \\
\text { Systemic motivational elem- } \\
\text { ents support learners' being } \\
\text { motivationally positioned to } \\
\text { put forth consistent effort. } \\
\text { Examine reasons for instruc- } \\
\text { tion in the larger workplace } \\
\text { system and determine how to } \\
\text { inform and align learners' } \\
\text { motivations and efforts. }\end{array}$ & $\begin{array}{l}\text { I. Students use mathematics, } \\
\text { physics, statics, dynamics, } \\
\text { etc. to design a device to } \\
\text { solve the problem. This } \\
\text { presents authentic use of } \\
\text { discrete information } \\
\text { selection and application } \\
\text { from the curriculum to } \\
\text { unique, open-ended prob- } \\
\text { lems. } \\
\text { 2. Course pulls together and } \\
\text { requires synthesis and } \\
\text { application of courses to } \\
\text { date (solids, thermal, } \\
\text { mechanical components), } \\
\text { supporting links across the } \\
\text { curriculum for competent } \\
\text { design. }\end{array}$ \\
\hline
\end{tabular}

\section{Redesign experiment in engineering education}

Having seen reduced engagement and synthesis of learning over the past few years, the course professor identified the need to improve students' motivation. The course redesign involved collecting data for a comprehensive set of motional characteristics and to show correlational clustering of characteristics and as trajectories of change, for one cohort of students over a single semester. Recognizing the complexity of factors that can influence students' motivation, learning, and design performance, and informed by the student motivational profile, the educator 
and a researcher-designer collaboratively redesigned the motivational aspects of the course, using the SUCCESS framework to structure that process. They proceeded intentionally and systematically, not assuming that any existing element (such as the course being project based, or the use of digital technologies) was already optimally motivating. Instead, they used existing design components as foundational starting points to build a more motivating, and dynamic, whole-course design. This required considering the course and learning environment as an integrative and coherent whole, together much more than the sum of its parts.

\section{Research design}

The study was a predictive correlational design, using an instructional intervention, assessing relevant factors at baseline and two subsequent points, on a theoretical change trajectory. The researchers proposed that motivational characteristics would demonstrate productive adjustment over time, where productive adjustment does not necessarily equate to positive directionality. The research questions addressed in this paper are:

1. What are the nature and characteristics of motivation these ME seniors initially have for a senior-level design course and how do they change over time?

2. What motivational characteristics are associated most strongly with students' overall motivation and how do the relationships among these characteristics change over the semester-long project-based design course?

\section{Overview of approach}

Course design. Principles of Engineering Design is a required undergraduate ME course, with 80 students enrolled in a single section. Immediately preceding the senior capstone design course, it gives students the opportunity to synthesize and integrate 80 previous hours of mathematics, physics, and other coursework through applied design projects. The semester-long course meets twice weekly for 75-min sessions, over a 14-week semester (28 meetings, 150 contact hours). The overarching course goal is for learners to demonstrate that with appropriate support they can do eight ME performance tasks (Table 2). These tasks are demonstrated in several assignments, as summarized in Figure 1. Some are completed individually and others in stable (semester-long) teams (of four to five students).

The course is taught by a tenured full professor in ME, who has taught this course annually for 13 years. His philosophy of instruction is linking engineering fundamentals to a range of professional applications through project-based learning. The professor uses lecture with questioning and discussion to introduce design principles linked to students' previous courses. Lectures are accompanied and illustrated by Powerpoint slides, presented in class and uploaded to the course 
Table 2. Course performance outcomes.

Specific Outcomes of Instruction:

Students will demonstrate (through supported performance) adequate knowledge and skill to:

I. Apply a systematic approach to solve design problems.

2. Plan the design process.

3. Generate, evaluate, and develop engineering design concepts by applying knowledge of facts, science, engineering science, and manufacturing principles.

4. Use analysis and simulation tools to understand design performance and then improve the design.

5. Manufacture an engineering design prototype.

6. Generate solid models and engineering drawings of a final design using 3D modeling software.

7. Give an oral presentation and demonstration of a design project.

8. Work on a team to complete a design project.

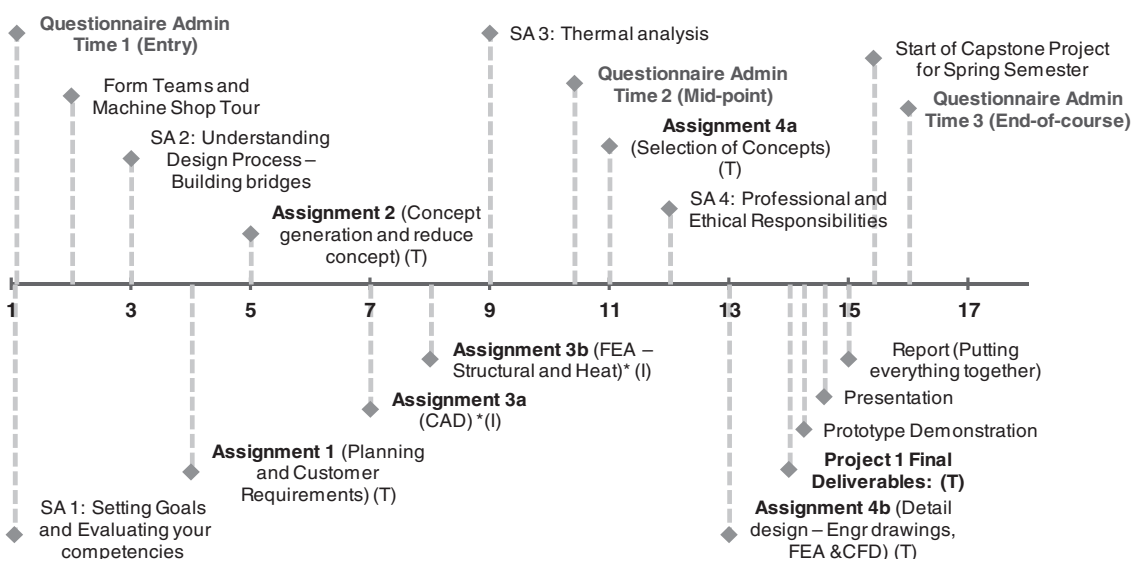

Figure I. Assignments and questionnaire administration timeline in weeks. Note:

Assignments are designated as Team (T) or individual (I).

management system website. The instructor also uses short assignments and inclass activities, which reinforce lecture materials, to facilitate understanding.

There are no prescheduled outside labs or content-based examinations. Students are required to meet in project teams, scheduled at their choice of times and locations, and course grades are composites of grades on the applied design assignments. Students synthesize and apply content holistically on projects, with instructor and peer support, feedback, and discussion. Projects are completed mostly outside of class, shared with the class as verbal narration and demonstration of functional prototypes, with written reports submitted to the instructor. Students spend about $60 \%$ of class time in lecture and $40 \%$ in various forms of dialog (questioning, discussion, feedback, in-class activities). 
Participant learners. Participants were 80 undergraduate university students enrolled in a single section of Principles of Engineering Design. Their general demographics are as follows: (1) gender (76 M, 5 F); (2) age 19-37 (M=22.79); (3) ethnicity (six Hispanic or Latino, 54 White, 10 Asian or Asian American, four multiracial, three American Indian or Alaska Native, three Black or African); (4) previous academic achievement (GPA; range: $2.52-4.08 ; \mathrm{M}=3.35$ on 4.0 scale); participating students were all senior ME majors with similar academic prior knowledge and experience, having taken the same requisite courses, over the previous two years (but not all together the same semesters). All entered the program with (required) high math and science aptitude scores (SAT average 1280; math 600-700; combined ACT 28.3; ACT Math range 32-25). They are preparing for similar future careers. IRB approval was obtained to conduct the study. The study included students who consented to participate.

Student diversity, in the program and course, has increased over recent years, across characteristics such as socioeconomic status, race and ethnicity, nations of origin, family status, and career experience. Gender balance is $88 \%$ male, $12 \%$ female; $90-95 \%$ are traditional students and only 5-10\% nontraditional; about $94 \%$ are US citizens, $6 \%$ international students, with 5-10\% non-Native English speakers.

Procedures. The course instructor and an instructional designer (a professor in instructional psychology and technology) identified key characteristics and variables from the motivational literature and collected data assessing these characteristics, to determine initial motivational profile and change over time among participants. With only one section of the course, no explicit nonintervention comparison group was possible. They systematically analyzed the instructional and motivational features of the course. Then they used the SUCCESS framework to add motivational enhancements to course activities and elements of the broader learning environment.

Data collection was administered by an individual other than the course instructor. All participant data were deidentified using personal code numbers, on data collection instruments and materials, and in the data set used for analysis. Some measures were administered multiple times (as appropriate) over the semester-long course (Time 1: course entry, Time 2: mid-point, Time 3: end of course), to support evaluating trajectory of change over time. All aspects of the study design were approved by the institution's human subjects research office. The schedule for all data sources is shown, integrated with other course activities, in Figure 1.

\section{Motivational measures}

Previously well-validated and reliable measures (contextualized for this group) were used to assess participants' cognitive, affective, and perceptual characteristics. All questionnaire instruments were standardized to seven-point Likert-type continuous numeric scales (anchored: $1=$ "strongly disagree" to $7=$ "strongly agree"). 
Below are summaries of the constructs and characteristics assessed in the study. Table 3 shows the design characteristics of these measures, including the names and definitions of the constructs or variables, length of scales, reliability (within this group), and sample items (questions). Each scale contained multiple and reverse questions. The Cronbach's Alpha for each scale (>0.75) indicated high level of reliability.

A. Individual differences-Predictive: A set of relatively stable individual differences has been demonstrated by previous research to influence motivation, learning, and performance. ${ }^{59}$ The cluster of individual difference characteristics assessed include: need for cognition, preference for interactive learning, need and tolerance for structure, conscientiousness, and persistence.

B. Individual differences-Motivational: The cluster of individual motivational differences assessed included: intrinsic and extrinsic reasons for choosing this major, learning and performance goals, future goals/relevance to future plans, self-efficacy for the course and for the profession of ME, individual success expectations in the course and career, and success expectations for the team (see Table 3 for details). This set of individual motivational differences (some stable and others more malleable) has been demonstrated by previous research to influence context-specific learning and performance. ${ }^{60}$

C. Perceptions of course climate and content: Perceptual factors of both the course content and the way the course was taught critically influence motivation, learning, and performance. Perceptions of content assessed included: value, relevance, and utility of the course content. Perceptions of course climate included: climate promoted by professor's style, interactions with peers, and team activities.

D. Perceptions of $M E-T h e$ profession: Perceptions of ME included the degree to which level of intelligence, hard work/challenge, and math-science aptitude and other perceived aptitudes and characteristics are needed to be successful in this field.

E. Motivational engagement and participation: Students' motivation was operationalized as engagement, effort, and participation in the course and course-related tasks (a widely accepted proxy measure for overall motivation in educational research). Measures included: self-report of cognitive engagement and effort on individual and team course-related tasks, self-report of behavioral engagement in individual activities, and peer report of behavioral engagement in team meetings and collaborative tasks.

\section{Analysis}

To address the research questions ("Research design" section), the researchers utilized a range of descriptive, comparative, and correlational methods. First, a 


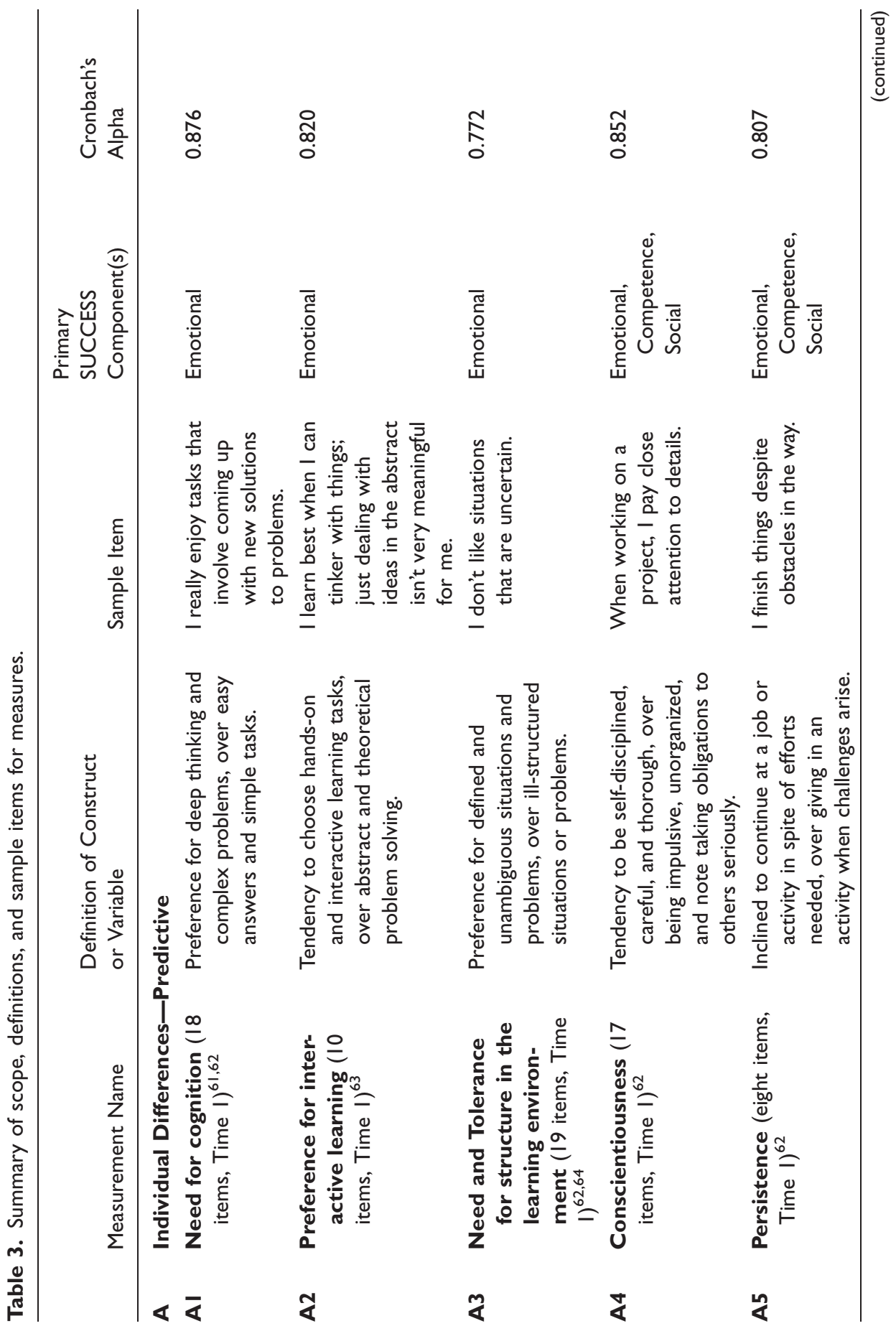




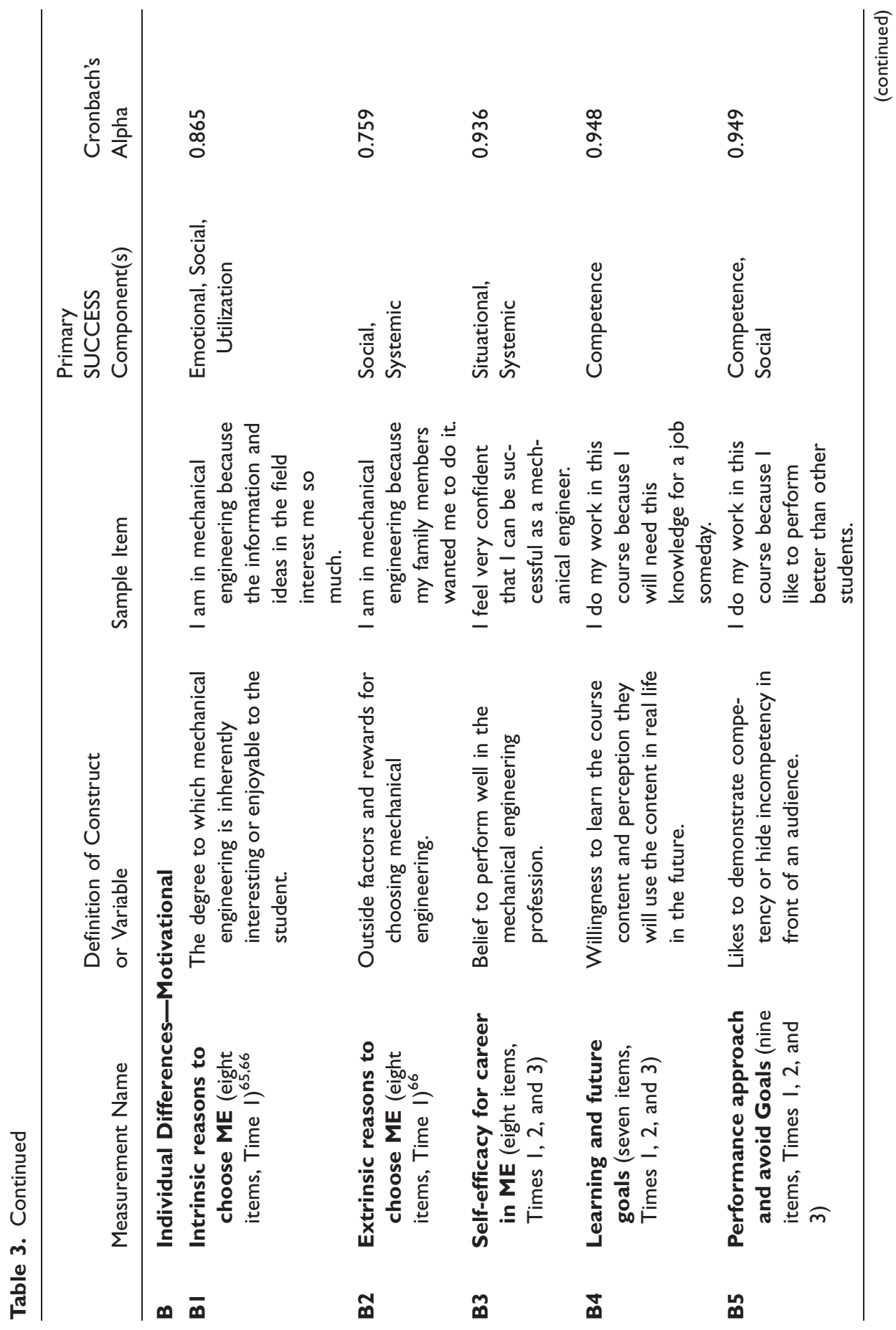




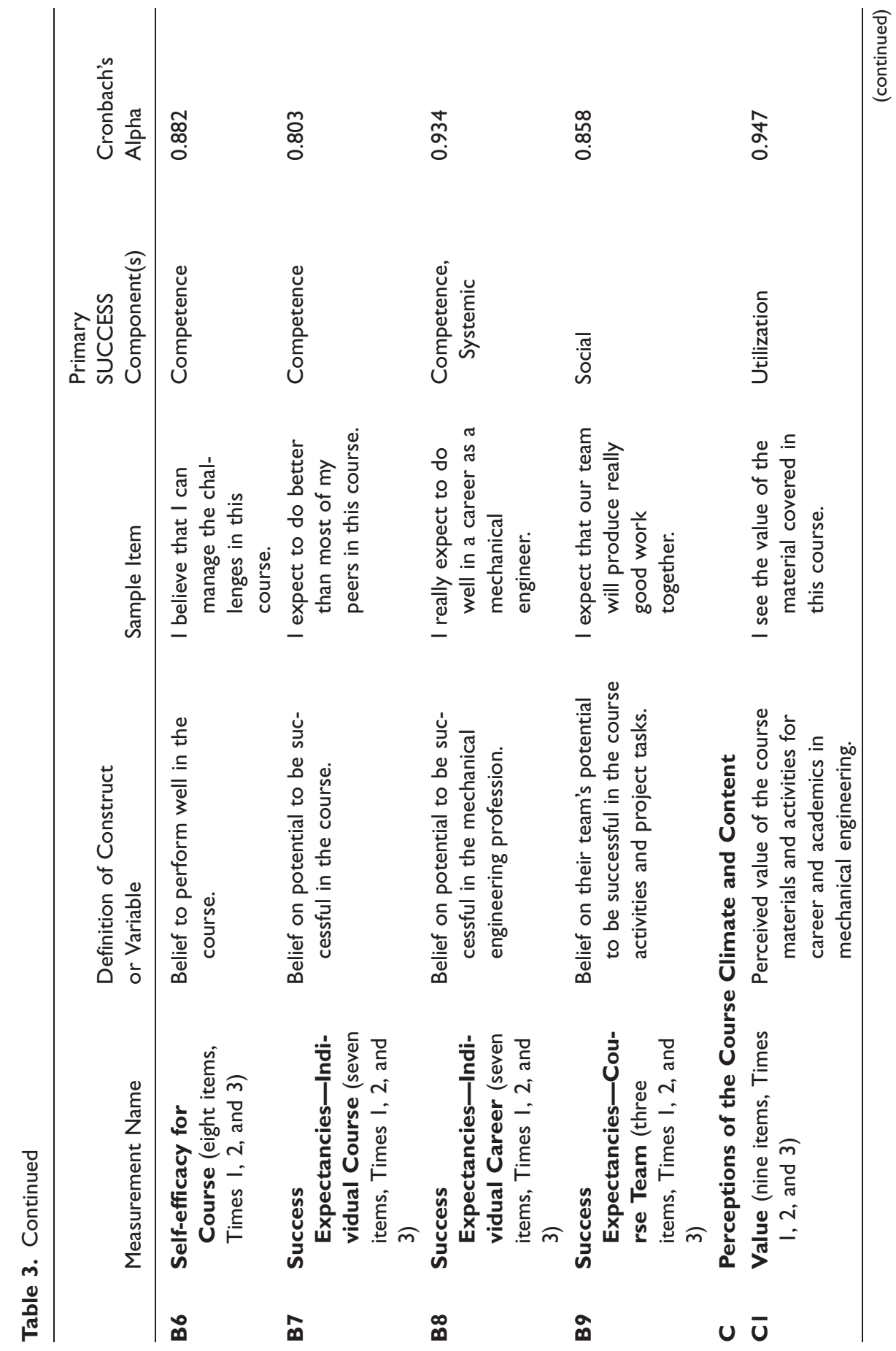




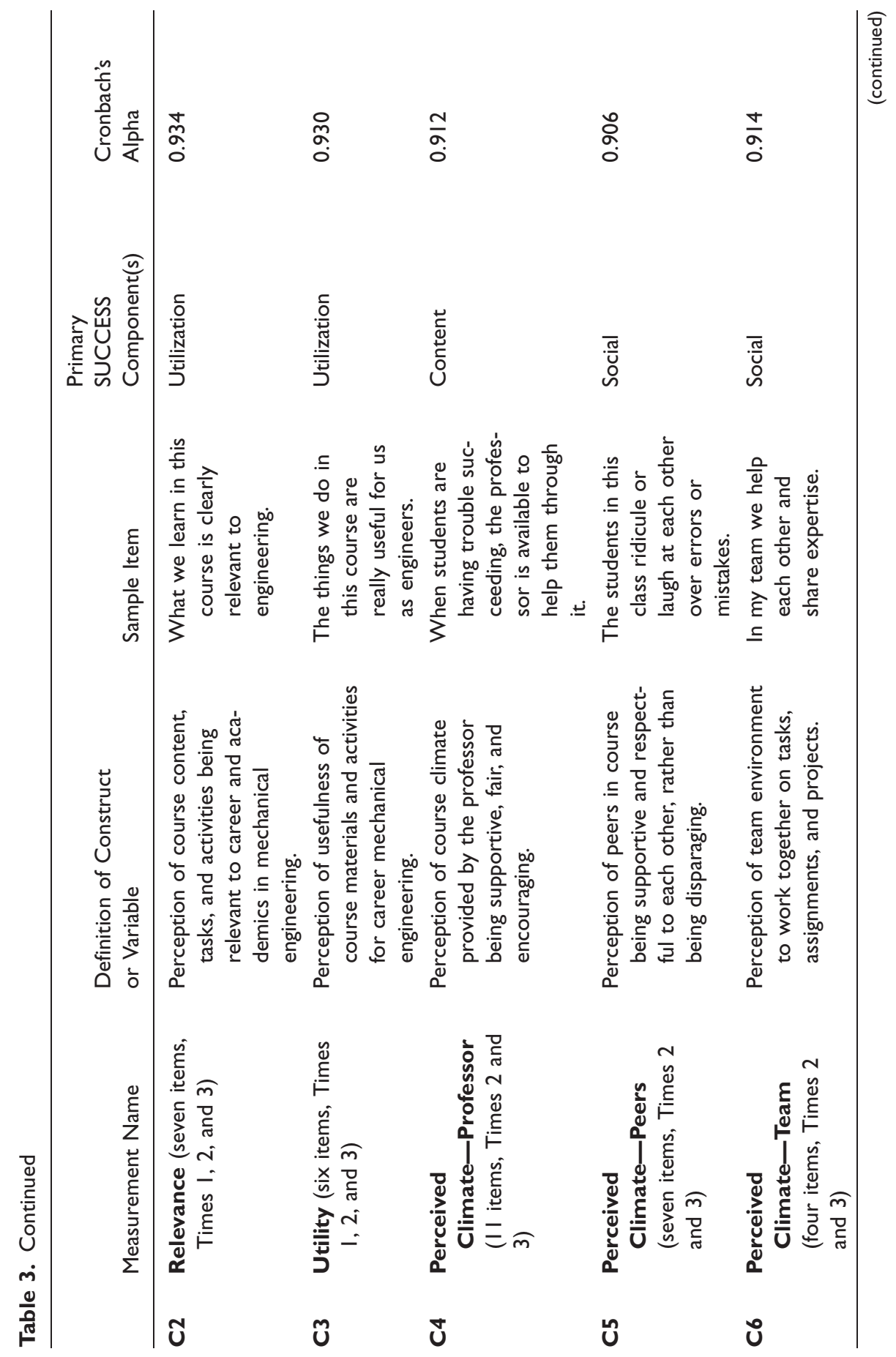




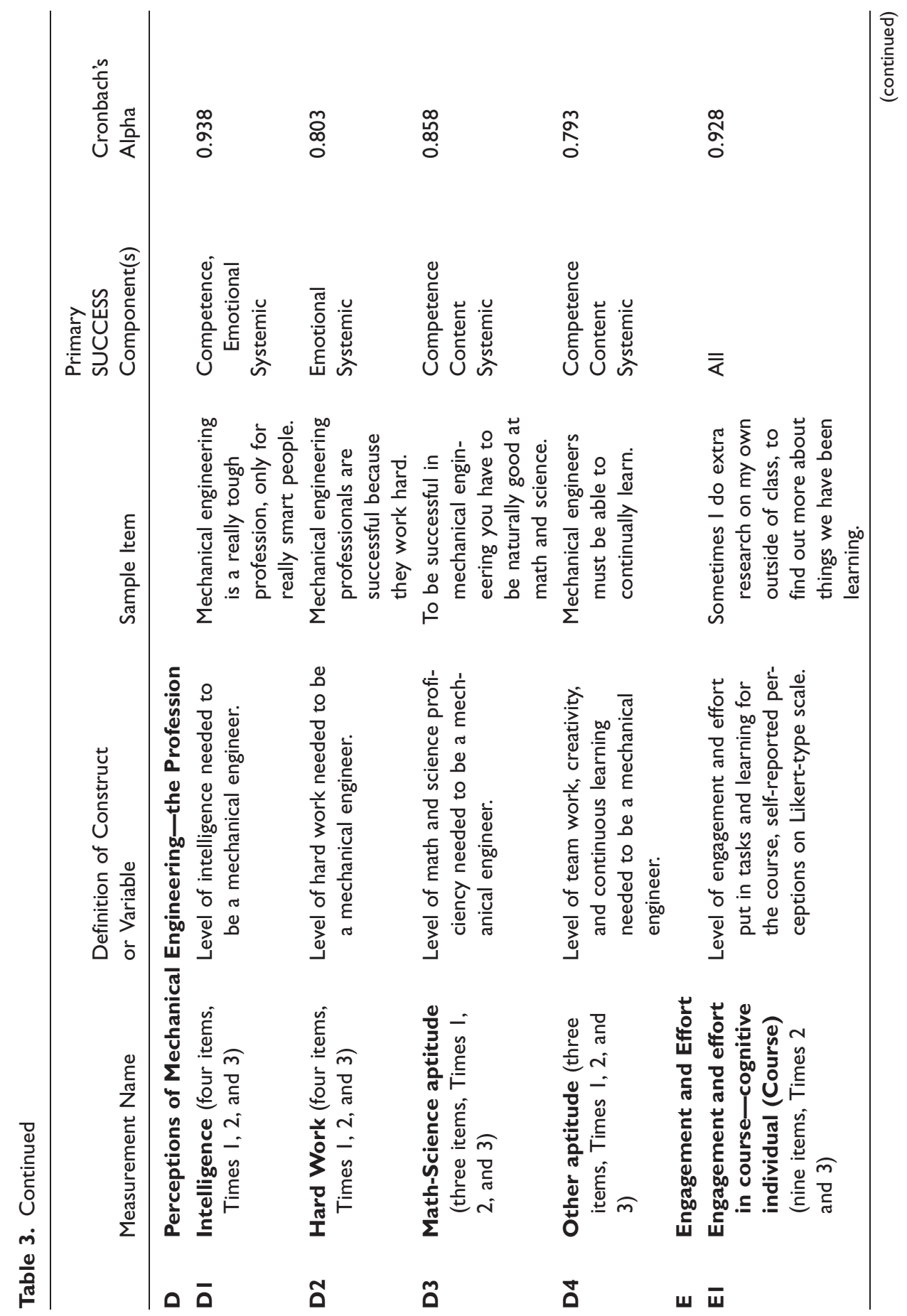




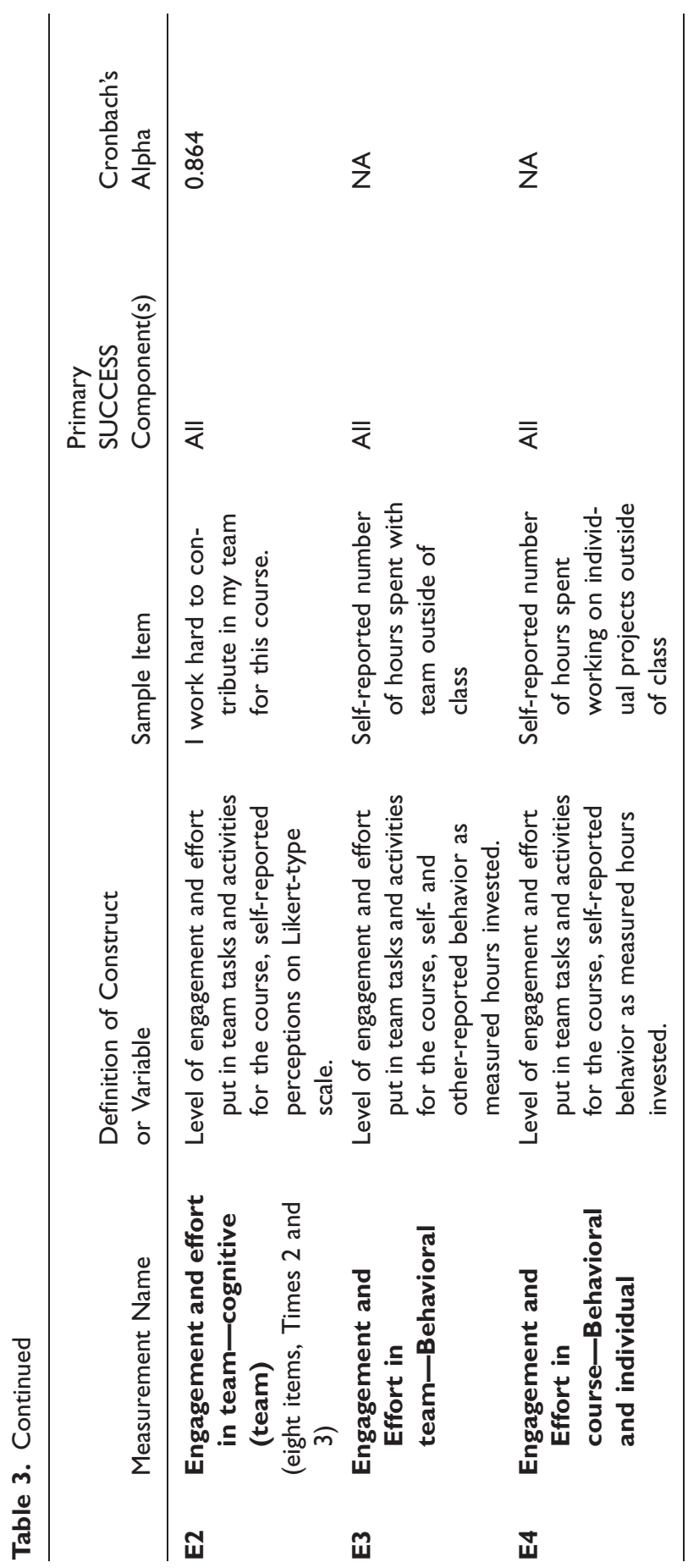


profile of the engineering students' initial motivational characteristics was generated by using mean scores of the relevant variables and examining the correlational connections among them. Second, changes in student characteristics were tracked over time by mapping the trajectories of mean scores across all three sets of assessments and conducting $t$-tests of significant patterns of change between the points of assessment. The relationships among the characteristics were examined by the correlational data at each point and over time. Third, point-in-time relationships between class climate and students' motivational profiles were investigated by explicitly aligning their characteristics at each point with course design and outcomes.

For all correlational data, a relationship is judged significant only if it meets the criteria of a magnitude of at least $r=.50$ and (two-tailed) significance of $p \leq .01$. For the paired-samples $t$-tests, the target level of significance was set at $p \leq .05$. Given the sample size $(\mathrm{N}=80)$, these constitute rigorous statistical standards. ${ }^{67}$

\section{Results}

\section{Initial motivational profile}

The first research question was: "What are the nature and characteristics of motivation these ME seniors initially have for a senior-level design course?" A profile of the engineering students' initial motivational characteristics was generated using mean scores on the relevant variables (Table 4) and by examining the correlational connections among them (Figure 2).

At the beginning of the semester, there was a cluster of characteristics with generally higher scores, and a set with relatively lower scores. The motivational and perceptual characteristics generally clustered high, identifying a positive profile overall, with room for additional refinement. The students evidenced higher need for cognition (5.21) and interactive learning environments (5.20) than for structured learning environments (4.34). Their related high persistence (5.75), conscientiousness (5.22), course self-efficacy (5.76), and success expectations (5.97) presented promise to carry them through challenges of design synthesis and application. Their combination of higher internal (5.25) than external (4.16) reasons for choosing ME, along with high career self-efficacy (5.97), supported engagement, learning, and development, as did higher learning and future goals (5.70) than performance goals (3.73). Initially high perceived value (5.41), relevance (5.51), and utility for the course (6.00), with beliefs that hard work (5.52) would lead to success more than innate intelligence (3.88), positioned them with a reasonably successful motivational profile. Overall, the integrated profile of these ME students began as positive and theoretically productive, so the motivational task of the course and professor was to maintain and support their existing motivation through the challenges of the design course and to promote motivation for those who were lacking in particular productive characteristics. 
Table 4. Summary statistics of students' initial motivational profile.

\begin{tabular}{|c|c|c|c|c|c|}
\hline & Measurement Name & Minimum & Maximum & Mean & Std Dev. \\
\hline A & \multicolumn{5}{|l|}{ Individual differences-predictive } \\
\hline Al & Need for cognition & 2.94 & 7.00 & 5.21 & 0.73 \\
\hline A2 & Preference for interactive learning & 2.20 & 6.50 & 5.20 & 0.85 \\
\hline A3 & $\begin{array}{l}\text { Need and tolerance for structure in the } \\
\text { learning environment }\end{array}$ & 3.18 & 6.29 & 4.34 & 0.59 \\
\hline A4 & Conscientiousness & 2.71 & 6.59 & 5.22 & 0.70 \\
\hline A5 & Persistence & 2.88 & 7.00 & 5.75 & 0.86 \\
\hline B & \multicolumn{5}{|l|}{ Individual differences-motivational } \\
\hline $\mathrm{BI}$ & Intrinsic reasons to choose ME & 2.25 & 7.00 & 5.78 & 0.78 \\
\hline B2 & Extrinsic reasons to choose $\mathrm{ME}$ & 1.88 & 6.75 & 4.16 & 0.94 \\
\hline B3 & Self-efficacy for career in ME & 2.50 & 7.00 & 5.97 & 0.81 \\
\hline B4 & Learning and future goals & 2.57 & 7.00 & 5.70 & 0.93 \\
\hline B5 & Performance approach and avoid goals & 1.00 & 6.22 & 3.73 & 1.15 \\
\hline B6 & Self-efficacy for course & 1.88 & 7.00 & 5.76 & 0.82 \\
\hline B7 & Success expectancies -indv course & 2.00 & 7.00 & 5.97 & 0.91 \\
\hline B8 & Success expectancies —indv career & 1.86 & 7.00 & 5.82 & 1.06 \\
\hline B9 & Success expectancies-course team & 1.50 & 7.00 & 5.98 & 0.94 \\
\hline C & \multicolumn{5}{|c|}{ Perceptions of the course climate and content } \\
\hline $\mathrm{Cl}$ & Value & 1.44 & 7.00 & 5.41 & 1.13 \\
\hline $\mathrm{C} 2$ & Relevance & 1.86 & 7.00 & 5.51 & 0.98 \\
\hline C3 & Utility & 1.00 & 7.00 & 6.00 & 1.00 \\
\hline D & \multicolumn{5}{|c|}{ Perceptions of Mechanical Engineering-the profession } \\
\hline DI & Intelligence & 1.00 & 6.50 & 3.88 & 1.37 \\
\hline D2 & Hard work & 1.00 & 7.00 & 5.52 & 1.05 \\
\hline D3 & Math-science aptitude & 1.00 & 7.00 & 4.16 & 1.27 \\
\hline D4 & Other aptitude & 1.00 & 7.00 & 6.09 & 0.96 \\
\hline
\end{tabular}

Initial high scores may also reflect past experiences and degree of challenge not entirely aligned with the challenge presented by the new course expectations. As this design course would be the first time these students were asked to fully integrate and synthesize all of their previous knowledge and skills in authentic, applied design, an adjustment was expected, a "reality check" of expectations. Such patterns had been found previously in similar studies in other disciplines. ${ }^{26,28}$ If and when that occurred, the task of the instructor would be to support the students' motivations to succeed through that experience, as they recalibrated. Beyond their individual initial levels, the students' motivation profile also consisted of the 


\begin{tabular}{|c|c|c|c|c|c|c|c|c|c|c|c|c|c|c|c|c|c|c|c|c|}
\hline \multirow{2}{*}{\multicolumn{2}{|c|}{\begin{tabular}{l|l} 
& A1 \\
A1 & 1
\end{tabular}}} & $\mathrm{~A} 2$ & A3 & A4 & A5 & B1 & $\mathrm{B} 2 \mathrm{~F}$ & B3 & B4 & B5 & B6 & B7 & B8 & B9 & $\mathrm{C} 1 \mathrm{C}$ & $\mathrm{C} 2 \mathrm{C}$ & $3 \mathrm{D}$ & D1 & D2 I & $\mathrm{D} 3 \mathrm{D} 4$ \\
\hline & & & & & & & & & & & & & & & & & & & & \\
\hline $\mathrm{A} 2$ & & 1 & & & & & & & & & & & & & & & & & & \\
\hline A3. & $\begin{array}{l}-.22 \\
.06\end{array}$ & \begin{tabular}{|l|}
-115 \\
.19 \\
\end{tabular} & & & & & & & & & & & \begin{tabular}{|l|l|} 
Mag \\
Mag \\
\end{tabular} & gnits & $\frac{\text { ude }}{u d e}$ & $\begin{array}{l}\geq 0 . \\
\geq 0.4\end{array}$ & & & & \\
\hline $\mathrm{A} 4$ & \begin{tabular}{|l}
.39 \\
4.00
\end{tabular} & $\begin{array}{l}26 \\
.02 \\
\end{array}$ & \begin{tabular}{|l|}
.25 \\
.03
\end{tabular} & 1 & & & & & & & & & & & & & & & & \\
\hline A5 & $\begin{array}{l}34 \\
.00\end{array}$ & $\begin{array}{l}.26 \\
.02 \\
\end{array}$ & $\begin{array}{l}16 \\
16 \\
\end{array}$ & $\begin{array}{l}.66 \\
.00 \\
\end{array}$ & 1 & & & & & & & & & & & & & & & \\
\hline $\mathrm{B} 1$ & $\begin{array}{l}.52 \\
.00\end{array}$ & $\begin{array}{l}44 \\
00 \\
\end{array}$ & $\begin{array}{l}-.07 \\
.53 \\
\end{array}$ & \begin{tabular}{|l|}
.55 \\
.00 \\
\end{tabular} & $\begin{array}{l}45 \\
00 \\
\end{array}$ & 1 & & & & & & & & & & & & & & \\
\hline B2 & $\begin{array}{l}-.08 \\
.48\end{array}$ & $\begin{array}{l}.04 \\
.75 \\
\end{array}$ & $\begin{array}{l}.35 \\
.00\end{array}$ & \begin{tabular}{|l|}
.07 \\
.57
\end{tabular} & $\begin{array}{l}.07 \\
.53 \\
\end{array}$ & $\begin{array}{l}.12 \\
.28\end{array}$ & 1 & & & & & & & & & & & & & \\
\hline B3 & 42 & $\begin{array}{l}48 \\
00\end{array}$ & .08 & $\begin{array}{l}.56 \\
.00 \\
\end{array}$ & $\begin{array}{l}.60 \\
.00\end{array}$ & \begin{tabular}{|l|}
.59 \\
.00 \\
\end{tabular} & $\begin{array}{l}.16 \\
.16\end{array}$ & & & & & & & & & & & & & \\
\hline B4 & $\begin{array}{l}.36 \\
.00\end{array}$ & $\begin{array}{l}.25 \\
.03 \\
\end{array}$ & $\begin{array}{l}.00 \\
.98 \\
\end{array}$ & $\begin{array}{l}.50 \\
.00 \\
\end{array}$ & $\begin{array}{l}44 \\
00\end{array}$ & $\begin{array}{l}.68 \\
.00 \\
\end{array}$ & & & 1 & & & & & & & & & & & \\
\hline B5 & -.26 & $\begin{array}{l}.06 \\
.62 \\
\end{array}$ & $\begin{array}{l}.16 \\
.17 \\
\end{array}$ & \begin{tabular}{|l|}
.22 \\
.06 \\
\end{tabular} & .03 & \begin{tabular}{|l|}
-.10 \\
.36 \\
\end{tabular} & 42. & .09 & -.05 & & & & & & & & & & & \\
\hline B6 & $\begin{array}{l}43 \\
00 \\
\end{array}$ & $\begin{array}{l}.26 \\
.02 \\
\end{array}$ & $\begin{array}{l}15 \\
21 \\
\end{array}$ & .66 & $\begin{array}{l}.58 \\
.00 \\
\end{array}$ & $\begin{array}{l}.51 \\
.00 \\
\end{array}$ & $\begin{array}{l}24 \\
03 .\end{array}$ & 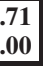 & $\begin{array}{l}.67 \\
.00 \\
\end{array}$ & \begin{tabular}{|l|}
.03 \\
.79 \\
\end{tabular} & 1 & & & & & & & & & \\
\hline B7 & $\begin{array}{l}.35 \\
.00\end{array}$ & $\begin{array}{l}30 \\
.01\end{array}$ & $\begin{array}{l}.23 \\
.05\end{array}$ & $\begin{array}{l}.60 \\
.00\end{array}$ & $\begin{array}{l}.58 \\
.00\end{array}$ & $\begin{array}{l}.38 \\
.00\end{array}$ & $\begin{array}{l}31 \\
01 .\end{array}$ & $\begin{array}{l}.62 \\
.00\end{array}$ & \begin{tabular}{l|}
.56 \\
.00
\end{tabular} & $\begin{array}{l}.14 \\
.23\end{array}$ & \begin{tabular}{|l|}
.74 \\
.00 \\
\end{tabular} & 1 & & & & & & & & \\
\hline B8 & .29 & $\begin{array}{l}41 \\
00\end{array}$ & $\begin{array}{l}09 \\
41\end{array}$ & $\begin{array}{l}42 \\
.00\end{array}$ & $\begin{array}{l}44 \\
00 \\
\end{array}$ & $\begin{array}{l}44 \\
.00\end{array}$ & 20 . & $\begin{array}{l}.70 \\
.00 \\
\end{array}$ & $\begin{array}{l}44 \\
00\end{array}$ & $\begin{array}{l}.02 \\
.89 \\
\end{array}$ & \begin{tabular}{|l}
.56 \\
.00 \\
\end{tabular} & $\begin{array}{l}.59 \\
.00 \\
\end{array}$ & 11 & & & & & & & \\
\hline B9 & $\begin{array}{l}.24 \\
.04\end{array}$ & $\begin{array}{l}36 \\
00 \\
\end{array}$ & $\begin{array}{l}22 \\
06\end{array}$ & $\begin{array}{l}43 \\
00 \\
\end{array}$ & $\begin{array}{l}45 \\
00\end{array}$ & $\begin{array}{l}42 \\
00 \\
\end{array}$ & $\begin{array}{l}43 \\
00 .\end{array}$ & \begin{tabular}{|l|}
.53 \\
.00 \\
\end{tabular} & $\begin{array}{l}.55 \\
.00 \\
\end{array}$ & $\begin{array}{l}.15 \\
.18 \\
\end{array}$ & $\begin{array}{l}.68 \\
.00 \\
\end{array}$ & $\begin{array}{l}.77 \\
.00 \\
\end{array}$ & \begin{tabular}{l|}
47 \\
00
\end{tabular} & 1 & & & & & & \\
\hline $\mathrm{C} 1$ & $\begin{array}{l}.31 \\
.01 \\
\end{array}$ & $\begin{array}{l}.29 \\
.01 \\
\end{array}$ & $\begin{array}{l}.03 \\
.80 \\
\end{array}$ & $\begin{array}{l}42 \\
00 \\
\end{array}$ & $\begin{array}{l}37 \\
.00 \\
\end{array}$ & .00 & $\begin{array}{l}27 \\
02\end{array}$ & $\begin{array}{l}.53 \\
.00 \\
\end{array}$ & $\begin{array}{l}.67 \\
.00 \\
\end{array}$ & $\begin{array}{l}-.03 \\
.80 \\
\end{array}$ & $\begin{array}{l}.64 \\
.00 \\
\end{array}$ & $\begin{array}{l}47 \\
00 \\
\end{array}$ & $\begin{array}{l}47 \\
.00\end{array}$ & \begin{tabular}{|l|}
.51 \\
.00 \\
\end{tabular} & 1 & & & & & \\
\hline $\mathrm{C} 2$ & .32 & $\begin{array}{l}.21 \\
.07\end{array}$ & $\begin{array}{l}.13 \\
26\end{array}$ & $\begin{array}{l}.43 \\
.00\end{array}$ & $\begin{array}{l}40 \\
00\end{array}$ & $\begin{array}{l}.55 \\
.00\end{array}$ & $\begin{array}{l}32 \\
.00\end{array}$ & $\begin{array}{l}.57 \\
.00\end{array}$ & $\begin{array}{l}.73 \\
.00\end{array}$ & $\begin{array}{l}.01 \\
.93\end{array}$ & $\begin{array}{l}.68 \\
.00\end{array}$ & $\begin{array}{l}.56 \\
.00\end{array}$ & $\begin{array}{l}.54 \\
.00\end{array}$ & \begin{tabular}{|l|}
.54 \\
.00
\end{tabular} & \begin{tabular}{l|}
.90 \\
.00
\end{tabular} & & & & & \\
\hline C3 & $\begin{array}{l}.26 \\
.02\end{array}$ & $\begin{array}{l}.38 \\
.00\end{array}$ & $\begin{array}{l}11 \\
35\end{array}$ & $\begin{array}{l}.39 \\
.00\end{array}$ & $\begin{array}{l}46 \\
00\end{array}$ & $\begin{array}{l}.62 \\
.00 \\
\end{array}$ & $\begin{array}{l}26 \\
02\end{array}$. & & $\begin{array}{l}.71 \\
.00 \\
\end{array}$ & $\begin{array}{l}.01 \\
.97\end{array}$ & $\begin{array}{l}.72 \\
.00\end{array}$ & $\begin{array}{l}.57 \\
.00 \\
\end{array}$ & $\begin{array}{l}.67 \\
.00\end{array}$ & $\begin{array}{l}.67 \\
.00 \\
\end{array}$ & & & & & & \\
\hline D1 & $\begin{array}{l}.03 \\
1.79\end{array}$ & .11 & \begin{tabular}{|l|}
.09 \\
.43
\end{tabular} & $\begin{array}{l}-.01 \\
.95\end{array}$ & $\begin{array}{l}.15 \\
.21\end{array}$ & $\begin{array}{l}16 \\
.16 \\
\end{array}$ & $\begin{array}{l}40 \\
00\end{array}$ & & $\begin{array}{l}.07 \\
.53 \\
\end{array}$ & $\begin{array}{l}.27 \\
.02 \\
\end{array}$ & \begin{tabular}{|l|}
.04 \\
.74
\end{tabular} & $\begin{array}{l}-.05 \\
.68\end{array}$ & $\begin{array}{l}-.03 \\
.82 \\
\end{array}$ & \begin{tabular}{|l|}
-.02 \\
.88 \\
\end{tabular} & \begin{tabular}{l|}
13 \\
29 \\
\end{tabular} & $\begin{array}{l}12-. \\
28\end{array}$ & & 1 & & \\
\hline D2 & .25 & $\begin{array}{l}32 \\
.00 \\
\end{array}$ & $\begin{array}{l}.06 \\
.64\end{array}$ & \begin{tabular}{|l}
.29 \\
.01
\end{tabular} & $\begin{array}{l}37 \\
.00 \\
\end{array}$ & $\begin{array}{l}49 \\
00\end{array}$ & 13. & & \begin{tabular}{|l|}
.51 \\
.00 \\
\end{tabular} & \begin{tabular}{|l|}
.03 \\
.83 \\
\end{tabular} & $\begin{array}{l}48 \\
00\end{array}$ & $\begin{array}{l}43 \\
.00 \\
\end{array}$ & .35 & \begin{tabular}{l|}
46 \\
00
\end{tabular} & $\begin{array}{l}.40 \\
.00\end{array}$ & \begin{tabular}{l|l|}
48 & .5 \\
00 & .0
\end{tabular} & & $\begin{array}{l}-.22 \\
.05\end{array}$ & & \\
\hline D3 & $\begin{array}{l}.13 \\
.27 \\
\end{array}$ & .06 & $\begin{array}{l}.11 \\
.34 \\
\end{array}$ & $\begin{array}{l}.02 \\
.85 \\
\end{array}$ & $\begin{array}{l}-.05 \\
.68 \\
\end{array}$ & $\begin{array}{l}20 \\
.08 \\
\end{array}$ & $\begin{array}{l}30 \\
01 .\end{array}$ & $\begin{array}{l}-.01 \\
.92 \\
\end{array}$ & \begin{tabular}{|l|}
.20 \\
.09 \\
\end{tabular} & $\begin{array}{l}.24 \\
.03 \\
\end{array}$ & \begin{tabular}{|l|}
-.05 \\
.66
\end{tabular} & $\begin{array}{l}.08 \\
.48 \\
\end{array}$ & .04 & \begin{tabular}{|l|}
.08 \\
.49 \\
\end{tabular} & $\begin{array}{l}.08 \\
.48\end{array}$ & $\begin{array}{l}17.0 \\
15.9\end{array}$ & & \begin{tabular}{|l|}
.69 \\
.00 \\
\end{tabular} & $\begin{array}{l}-.13 \\
.24 \\
\end{array}$ & \\
\hline D4 & $\begin{array}{l}.25 \\
.03\end{array}$ & $\begin{array}{l}36 \\
.00\end{array}$ & $\begin{array}{l}31 \\
.01\end{array}$ & $\begin{array}{l}.50 \\
.00\end{array}$ & $\begin{array}{l}48 \\
.00\end{array}$ & $\begin{array}{l}.61 \\
.00\end{array}$ & $\begin{array}{l}31 \\
.01\end{array}$ & & $\begin{array}{l}.56 \\
.00\end{array}$ & $\begin{array}{l}.19 \\
.10\end{array}$ & $\begin{array}{l}.53 \\
.00\end{array}$ & $\begin{array}{l}49 \\
.00\end{array}$ & $\begin{array}{l}.35 \\
.00\end{array}$ & $\begin{array}{l}.55 \\
.00 \\
\end{array}$ & $\begin{array}{l}45 \\
00\end{array}$ & \begin{tabular}{l|l}
49 & .6 \\
00 & .0
\end{tabular} & \begin{tabular}{l|l}
61 & \\
00 &.
\end{tabular} & \begin{tabular}{|l|}
13 \\
.27 \\
\end{tabular} & \begin{tabular}{l|}
.52 \\
.00 \\
\end{tabular} & \begin{tabular}{|l|}
.23 \\
.05
\end{tabular} \\
\hline
\end{tabular}

Figure 2. Correlation matrix for Timel. Index of Measurement Names (Figures 2, 4, and 5, not all measurements are present in a specific figure): $A=$ Individual Differences-Predictive; $A I=$ Need for cognition; $A 2=$ Preference for interactive learning; $A 3=$ Need and Tolerance for structure in the Learning Environment; $A 4=$ Conscientiousness; $A 5=$ Persistence; $\mathrm{B}=$ Individual Differences-Motivational; $\mathrm{BI}=$ Intrinsic Reasons to Choose ME; $\mathrm{B} 2=$ Extrinsic Reasons to Choose ME; B3 = Self-efficacy for Career in ME; B4 = Learning and Future Goals; B5 = Performance Approach and Avoid Goals; B6 = Self-efficacy for Course; B7 = Success Expectancies-Individual Course; B8 = Success Expectancies - Individual Career; B9 = Success Expectancies-Course Team; $\mathrm{C}=$ Perceptions of the Course Climate and Content; $\mathrm{Cl}=$ Value; C2 = Relevance; C3 = Utility; C4 = Perceived Climate-Professor; C5 = Perceived Climate-Peers; C6 = Perceived Climate-Team; D = Perceptions of Mechanical Engineering一the Profession; DI = Intelligence; D2 = Hard Work; D3 = Math-Science aptitude; D4 = Other aptitude; $\mathrm{E}=$ Self-Reported Behavioral Engagement; $\mathrm{EI}=$ Engagement and Effort in Course; E2 = Engagement and Effort in team; E3 = Self-Report-Hours w/Team; E4 = SelfReport-Hours Individual. 
interrelations of these characteristics to one another, as demonstrated through intercorrelations.

Among this group of ME students, there were familiar and theoretically consistent patterns of relationships, and some that had not previously been reported in published studies of engineering education. Self-Efficacy for the ME Profession (B3) and Learning and Future Goals (B4) were closely related to success expectations for course and career. Learning and Future Goals related to students' perception of value $(\mathrm{C} 1)$, relevance $(\mathrm{C} 2)$, and utility $(\mathrm{C} 3)$ of the design course. Intrinsic (B1), rather than extrinsic (B2), reasons for selecting ME as a profession correlated with overall motivation. Student perception of other aptitudes (D4) (working in team, continuous learning, and creativity) needed by mechanical engineers was correlated better with self-efficacy for ME as a profession, course, and other factors, than were science and math aptitude (D3). However, students who thought $\mathrm{ME}$ required natural intelligence (D1) were also likely to think it required math and science aptitude (D3), but these did not correlate with motivation overall. Most students believed that $\mathrm{ME}$ requires collaborative thinking and creativity to tackle challenging problems, which was consistent with their previous experience with this program. Conscientiousness (A4) and persistence (A5) were correlated with selfefficacy for ME as a profession (B3), self-efficacy for the design course (B6), and success expectations for the design course (B8).

\section{Motivational trajectories of change over time}

The incremental and sequential changes were examined in design students' motivation-related characteristics over time, by mapping the trajectories of mean scores across all three points in time. Comparing all three points provided more complete information on trajectory, illuminating change that a simpler prepost comparison would overlook. The correlational data at each point for any relational shifts were also examined. These are divided into individual (more stable) motivational characteristics (Figure 3(a)), interpersonal and team (more contextual characteristics) (Figure 3(b)), and environmental (instructionally malleable characteristics) (Figure 3(c) and (d)).

As illustrated visually in the trajectory-of-change graph (Figure 3), a number of motivational characteristics demonstrated adjustments over the course, as students adapted to the new course and skill demands, to the learning environment, and to each other. Some motivational characteristics dipped and then recovered to varying degrees. Characteristics with statistically significant dips are perceptions of the content (value, utility, and relevance) along with learning and future goals. The course involved students using design tools and steps that required a higher level of cognitive engagement rather than focusing on test-and-refine processes, which most students are familiar and comfortable with. To learners who have previously worked in very hands-on practice, the combination of complex synthesis and managing abstract concepts appears to have created some surprise and confusion mid-term, but then these perceptions recovered as they sorted out the new demands and synthesized to 
(a)

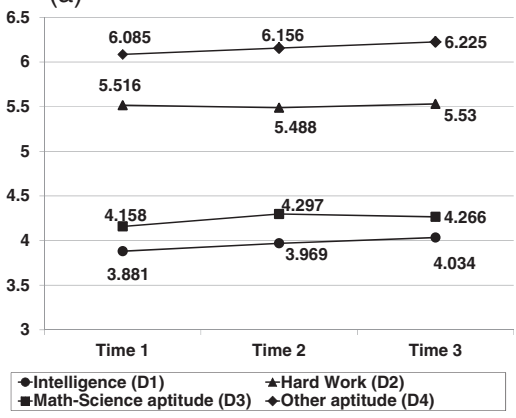

(c)

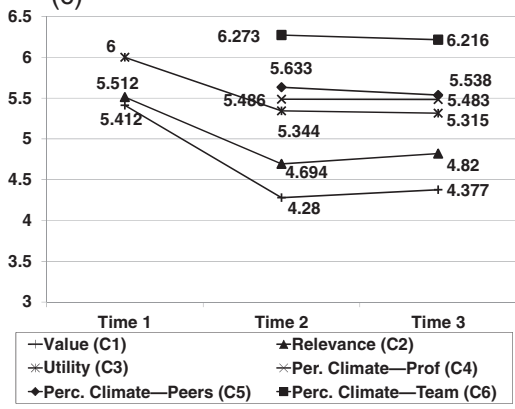

(b)

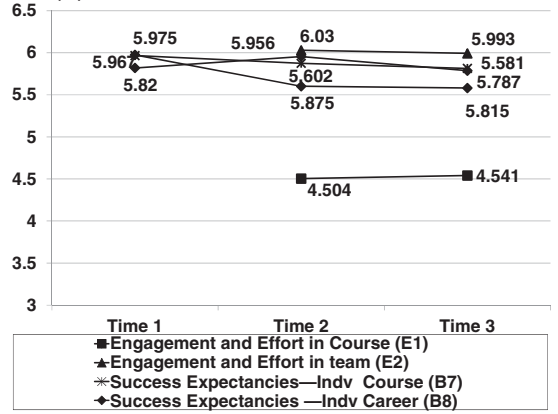

(d)

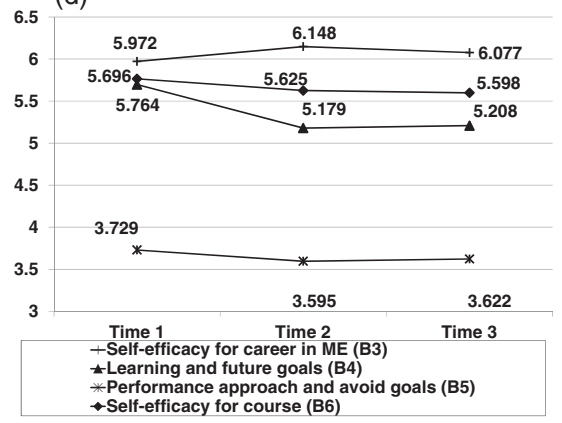

Figure 3. Changes in design students' motivation-related characteristics over time: (a) Individual motivational, (b) interpersonal and team, (c) environmental-course (perceptions of the course climate and content), (d) environmental-profession (perceptions of ME-the profession).

design goals near the end. Patterns on team learning indicated initial dips that did not recover. Learners in the ME curriculum have limited experience working in teams in previous course work. Hence, inefficiencies of team functioning could have contributed to this significant decrease in mean scores, because individuals might have felt that it took much longer to learn the material in a team setting and they could have learned the same things in a shorter time with less effort.

Although there was not a statistically significant change (Figure 3), a number of factors peaked and then leveled, demonstrating upward motion followed by a slight drop. These included: self-efficacy for career in ME, success expectations individually for career, and perception of math-science aptitude needed for the ME profession. It is believed that as seniors, the students have already built perspectives and expectations on their abilities to succeed as mechanical engineers. Each student's perspective, being the product of their undergraduate experience, is not likely to change because of the single design course. Even then, the team experience and synthesis of previously learned engineering content contributed productively to their motivational profile. 
Student perceptions of the intelligence and other aptitudes (team work, creativity, and continuous learning) required for ME had a slight upward trend for the semester. As seniors, students already have well-formed perceptions of ME as a profession, but working on a design project in a team environment that involved creativity and application of content from previous engineering courses reinforced their motivational characteristics.

From Time 1 to Time 3, there was no statistically significant overall change in students' engagement and effort in course and team, perceived climate-professor, and hard work needed to be a ME. These motivational characteristics remained relatively stable over time. Students have already developed motivations for performing well academically. Team projects fostered a collaborative, team-based atmosphere. Student perception of the professor's style did not change significantly over time. The instructor made his expectations clear at the beginning of the course and followed the course outline, aligning learning goals, content, and assessments. Learners found the climate supportive and stable over time. The instructor presented the material in a way that kept students engaged throughout the course. The course was reasonably challenging so that individuals felt continuing to put forth effort would lead to success.

There were several motivational characteristics with slight downward trend. These included: self-efficacy for the course, success expectancies as individual in course, and perceived climate of peers. The demands of design are different from many of the students' previous course experiences, more complex and integrative, requiring willingness to take risks, innovate, problem-solve, and imagine beyond the known. Overall, the trajectories of maintaining generally productive and stable motivational characteristics over the semester, given novel demands and the complexity of the design tasks indicate a positive motivational environment.

\section{Changes over time for correlational patterns in motivational profile}

The shifts in clustering across characteristics in students' motivational characteristics were examined to identify adjustments and restructuring of their perceptual frameworks with regard to the course, their place within it, and how it related to their professional identities and futures. The incremental, sequential sets of motivational relationships and their correspondence with class activities were examined by explicitly aligning the point-in-time profiles with course design and outcomes, and examining these data snapshots for convergence and divergence.

The number of significant correlations, at magnitudes 0.05 or 0.04 , among different motivational characteristics reduced, and relationships among the motivational factors converged as the course progressed (Figure 5). The total of significant correlations at each point in time (at both magnitudes) was as follows: Time 1: 34 at .04, 59 at .05; Time 2: 32 at .04, 33 at .05; Time 3: 30 at .04, 49 at .05. Some of the nonmalleable motivational characteristics (conscientiousness, persistence, and intrinsic reasons to choose $\mathrm{ME}$ ) were highly correlated with other nonmalleable characteristics (A) during Time 1 (Figure 2). There were significant 


\begin{tabular}{|c|c|c|c|c|c|c|c|c|c|c|c|c|c|c|c|c|c|c|c|c|c|c|c|c|c|c|c|}
\hline & A1 & A $2 A$ & A3 & A4 4 & $\mathrm{~A} 5$ & B1 & B2 & B3 & B4 & B5 & B6 & B & $\begin{array}{l}7 \mathrm{~B} \\
\end{array}$ & 38 & B9 C1 C & $\mathrm{C} 2 \mathrm{C}$ & C3 & C4 & C5 & C6 D1 I & \begin{tabular}{|l|l} 
D2 & 1 \\
\end{tabular} & D3 I & D4 & E1 & E2 & E3 & E4 \\
\hline A1 & & & & & & & & & & & & & & & & & & & & & & & & & & & \\
\hline $\mathrm{A} 2$ & $\begin{array}{l}.11 \\
.34\end{array}$ & & & & & & & & & & & & & & & & & & & & & & & & & & \\
\hline A3 & -.22 & -.15 & 1 & & & & & & & & & & & & & & & & \multirow{2}{*}{\multicolumn{4}{|c|}{$\begin{array}{l}\text { Magnitude } \geq 0.5 \\
\text { Magnitude } \geq 0.4\end{array}$}} & & & & & \\
\hline & .06 & & & & & & & & & & & & & & & & & & & & & & & & & & \\
\hline A4 & .37 & .26 & & 1 & & & & & & & & & & & & & & & & & & & & & & & \\
\hline A5 & .34 & & & & & & & & & & & & & & & & & & & & & & & & & & \\
\hline B1 & $\begin{array}{l}.52 \\
.00\end{array}$ & .44 & & .55 & & 1 & & & & & & & & & & & & & & & & & & & & & \\
\hline B2 & $\begin{array}{r}-.08 \\
.48 \\
\end{array}$ & .04 & .35 & .07 & $\begin{array}{l}.07 \\
.53\end{array}$ & & 1 & & & & & & & & & & & & & & & & & & & & \\
\hline B3 & $\begin{array}{l}.49 \\
.00\end{array}$ & .16 & & .18 & $\begin{array}{l}.28 \\
.03\end{array}$ & $\begin{array}{l}.31 \\
.01 \\
\end{array}$ & & & & & & & & & & & & & & & & & & & & & \\
\hline B4 & $\begin{array}{l}.08 \\
.55\end{array}$ & .05 & .23 & .04 & .00 & $\begin{array}{l}.27 \\
.03\end{array}$ & & \begin{tabular}{|l|}
.31 \\
.01 \\
\end{tabular} & 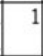 & & & & & & & & & & & & & & & & & & \\
\hline B5 & -.18 & .09 & & .16 & $\begin{array}{l}-.11 \\
.39 \\
\end{array}$ & $\begin{array}{r}-.21 \\
.09 \\
\end{array}$ & .22 & .09 & .26 & 1 & & & & & & & & & & & & & & & & & \\
\hline B6 & $\begin{array}{l}.23 \\
.07\end{array}$ & & & .14 & $\begin{array}{l}.17 \\
.18\end{array}$ & $\begin{array}{l}.19 \\
.14\end{array}$ & .00 & $\begin{array}{l}.54 \\
.00 \\
\end{array}$ & $\begin{array}{l}.56 \\
.00\end{array}$ & .07 & 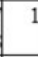 & & & & & & & & & & & & & & & & \\
\hline B7 & .18 & .18 & $\begin{array}{l}.06 \\
.67\end{array}$ & $\begin{array}{l}.19 \\
.15\end{array}$ & $\begin{array}{l}.24 \\
.06 \\
\end{array}$ & $\begin{array}{l}.03 \\
.81 \\
\end{array}$ & $\begin{array}{l}.24 \\
.06 \\
\end{array}$ & .48 & $\begin{array}{l}.17 \\
.19 \\
\end{array}$ & $\begin{array}{l}.12 \\
.34 \\
\end{array}$ & .47 & & 1 & & & & & & & & & & & & & & \\
\hline B8 & .41 & $.16-$ & & .32 & .46 & $\begin{array}{l}.33 \\
.01 \\
\end{array}$ & $\begin{array}{l}.14 \\
.28 \\
\end{array}$ & \begin{tabular}{|l|}
.74 \\
.00 \\
\end{tabular} & .29 & $\begin{array}{l}.03 \\
.84 \\
\end{array}$ & .47 & .5 & & 1 & & & & & & & & & & & & & \\
\hline B9 & $\begin{array}{l}.16 \\
.23 \\
\end{array}$ & $\begin{array}{l}.13 \\
.32\end{array}$ & $\begin{array}{l}33 \\
.01\end{array}$ & .06 & $\begin{array}{l}.10 \\
.46 \\
\end{array}$ & $\begin{array}{l}.23 \\
.07 \\
\end{array}$ & $\begin{array}{l}.06 \\
.64 \\
\end{array}$ & $\begin{array}{l}.54 \\
.00 \\
\end{array}$ & $\begin{array}{l}.50 \\
.00 \\
\end{array}$ & $\begin{array}{l}.27 \\
.03 \\
\end{array}$ & $\begin{array}{l}.41 \\
.00\end{array}$ & 1.4 & & $\begin{array}{l}50 \\
00 \\
\end{array}$ & 1 & & & & & & & & & & & & \\
\hline $\mathrm{C} 1$ & $\begin{array}{r}.10 \\
.43 \\
\end{array}$ & $\begin{array}{l}-.03 \\
.84 \\
\end{array}$ & $\begin{array}{l}17 \\
.19\end{array}$ & .23 & $\begin{array}{r}. .11 \\
.40 \\
\end{array}$ & $\begin{array}{l}.09 \\
.48 \\
\end{array}$ & $\begin{array}{l}.09 \\
.48 \\
\end{array}$ & \begin{tabular}{|l|}
.29 \\
.02 \\
\end{tabular} & \begin{tabular}{|l|}
.71 \\
.00 \\
\end{tabular} & $\begin{array}{l}.30 \\
.02 \\
\end{array}$ & .46 & & $\begin{array}{ll}13 & .2 \\
32.1\end{array}$ & $\begin{array}{l}20 \\
11 .\end{array}$ & $\begin{array}{ll}.45 & 1 \\
.00 & \\
\end{array}$ & & & & & & & & & & & & \\
\hline $\mathrm{C} 2$ & $\begin{array}{r}.02 \\
.85 \\
\end{array}$ & $\begin{array}{r}.08 \\
.56\end{array}$ & $\begin{array}{l}01 \\
.97\end{array}$ & $\begin{array}{l}21 \\
.10 \\
\end{array}$ & $\begin{array}{r}.10 \\
.45 \\
\end{array}$ & $\begin{array}{r}.00 \\
1\end{array}$ & $\begin{array}{l}.29 \\
.02 \\
\end{array}$ & \begin{tabular}{|l|}
.33 \\
.01 \\
\end{tabular} & $\begin{array}{l}.60 \\
.00 \\
\end{array}$ & .41 & .49 & & & \begin{tabular}{l|l}
33 &. \\
01 &.
\end{tabular} & \begin{tabular}{l|l|}
.41 & .82 \\
.00 & .00 \\
\end{tabular} & 1 & & & & & & & & & & & \\
\hline C3 & $\begin{array}{r}-.10 \\
.46\end{array}$ & .05 & $\begin{array}{l}15 \\
24\end{array}$ & $\begin{array}{l}21 \\
.10 \\
\end{array}$ & $\begin{array}{r}-.07 \\
.58 \\
\end{array}$ & $\begin{array}{l}.09 \\
.51\end{array}$ & $\begin{array}{l}.17 \\
.17 \\
\end{array}$ & \begin{tabular}{|l|}
.36 \\
.00 \\
\end{tabular} & $\begin{array}{l}.67 \\
.00 \\
\end{array}$ & $\begin{array}{l}.36 \\
.00 \\
\end{array}$ & $\begin{array}{l}.50 \\
.00\end{array}$ & & $\begin{array}{ll}27 \\
03 & .7 \\
03 & \end{array}$ & \begin{tabular}{l|l}
29 &. \\
02 &.
\end{tabular} & \begin{tabular}{l|l|}
.59 & .83 \\
.00 & .00
\end{tabular} & .81 & 1 & & & & & & & & & & \\
\hline C4 & $\begin{array}{l}.12 \\
.35\end{array}$ & $\begin{array}{l}.03 \\
.84\end{array}$ & $\begin{array}{l}.09 \\
.49\end{array}$ & $\begin{array}{l}.03 \\
.81\end{array}$ & $\begin{array}{l}.04 \\
.78\end{array}$ & $\begin{array}{l}.08 \\
.55\end{array}$ & $\begin{array}{l}.11 \\
.41\end{array}$ & $\begin{array}{l}.41 \\
.00\end{array}$ & $\begin{array}{l}.59 \\
.00\end{array}$ & $\begin{array}{l}.19 \\
.12\end{array}$ & $\begin{array}{l}.60 \\
.00\end{array}$ & & & \begin{tabular}{l|l}
32 &. \\
01 &.
\end{tabular} & \begin{tabular}{l|l|l|}
.44 & .70 & . \\
.00 & .00 & . \\
\end{tabular} & .68 & $\begin{array}{l}.69 \\
.00\end{array}$ & 1 & & & & & & & & & \\
\hline C5 & $\begin{array}{l}.02 \\
.88\end{array}$ & .10 & $\begin{array}{l}17 \\
.18\end{array}$ & $\begin{array}{l}.15 \\
.25\end{array}$ & $\begin{array}{l}.34 \\
.01\end{array}$ & $\begin{array}{l}.25 \\
.05 \\
\end{array}$ & $\begin{array}{r}-.01 \\
.92 \\
\end{array}$ & .41 & .40 & $\begin{array}{l}.05 \\
.68 \\
\end{array}$ & $\begin{array}{l}.43 \\
.00\end{array}$ & & 28. & $\begin{array}{l}37 \\
00\end{array}$ & $\begin{array}{l}.37 .47 \\
.00 .00\end{array}$ & $\begin{array}{l}.38 \\
.00\end{array}$ & .36 & $\begin{array}{l}.60 \\
.00\end{array}$ & & & & & & & & & \\
\hline C6 & $\begin{array}{l}.08 \\
.54\end{array}$ & $\begin{array}{l}.02 \\
.89\end{array}$ & $\begin{array}{l}.06 \\
.65\end{array}$ & .30 & $\begin{array}{l}.35 \\
.01\end{array}$ & .12 & $\begin{array}{l}.03 \\
.80\end{array}$ & $\begin{array}{l}.25 \\
.05 \\
\end{array}$ & $\begin{array}{l}.11 \\
.41\end{array}$ & $\begin{array}{l}.01 \\
.91\end{array}$ & .48 & & & \begin{tabular}{|l|l|}
28 & \\
03 &
\end{tabular} & $\begin{array}{ll}.23 & .14 \\
.07 & .27\end{array}$ & $\begin{array}{l}.17 \\
.17\end{array}$ & $\begin{array}{l}.16 \\
.20\end{array}$ & \begin{tabular}{|l|}
.39 \\
.00 \\
\end{tabular} & $\begin{array}{l}.51 \\
.00 \\
\end{array}$ & 1 & & & & & & & \\
\hline D1 & $\begin{array}{l}.05 \\
.69\end{array}$ & $\begin{array}{l}.16 \\
.21\end{array}$ & $\begin{array}{l}.18 \\
.17\end{array}$ & $\begin{array}{l}.10 \\
.46\end{array}$ & $\begin{array}{l}.15 \\
.24\end{array}$ & $\begin{array}{l}.27 \\
.03\end{array}$ & $\begin{array}{l}.37 \\
.00\end{array}$ & $\begin{array}{l}.07 \\
.60\end{array}$ & $\begin{array}{l}.14 \\
.26\end{array}$ & $\begin{array}{l}.24 \\
.06\end{array}$ & $\begin{array}{l}.16 \\
.20\end{array}$ & & & $\begin{array}{l}17 \\
19\end{array}$ & $\begin{array}{lll}10 & .17 \\
.42 & .19\end{array}$ & \begin{tabular}{l|l}
.23 \\
.07
\end{tabular} & $\begin{array}{l}.08 \\
.55 \\
\end{array}$ & $\begin{array}{l}-.05 \\
.67\end{array}$ & \begin{tabular}{|l|}
.03 \\
.83 \\
\end{tabular} & $\begin{array}{l}.08 \\
.55\end{array}$ & & & & & & & \\
\hline D2 & $\begin{array}{r}-.08 \\
.56\end{array}$ & $\begin{array}{l}.12 \\
.35\end{array}$ & $\begin{array}{l}.05 \\
.71\end{array}$ & .06 & $\begin{array}{r}-.02 \\
.90\end{array}$ & $\begin{array}{l}.14 \\
.27\end{array}$ & $\begin{array}{r}-.12 \\
.35 \\
\end{array}$ & $\begin{array}{l}.19 \\
.13 \\
\end{array}$ & $\begin{array}{l}.27 \\
.03 \\
\end{array}$ & $\begin{array}{l}.01 \\
.94 \\
\end{array}$ & $\begin{array}{l}.06 \\
.64\end{array}$ & & & $\begin{array}{l}16 \\
21\end{array}$ & $\begin{array}{ll}.24 & .29 \\
.05 & .02\end{array}$ & $\begin{array}{l}.27 \\
.03\end{array}$ & $\begin{array}{l}.26 \\
.04 \\
\end{array}$ & $\begin{array}{l}.24 \\
.06 \\
\end{array}$ & $\begin{array}{l}.47 \\
.00\end{array}$ & $\begin{array}{l}.07-.07 \\
.61 .56\end{array}$ & 1 & & & & & & \\
\hline D3 & $\begin{array}{r}-.03 \\
.84\end{array}$ & $\begin{array}{l}.23 \\
.07\end{array}$ & $\begin{array}{l}.13 \\
.31\end{array}$ & .06 & $\begin{array}{l}.03 \\
.82\end{array}$ & $\begin{array}{l}.32 \\
.01\end{array}$ & $\begin{array}{l}.44 \\
.00\end{array}$ & \begin{tabular}{|l|}
.03 \\
.81
\end{tabular} & $\begin{array}{l}.13 \\
.29\end{array}$ & $\begin{array}{l}.26 \\
.04\end{array}$ & $\begin{array}{l}.02 \\
.87\end{array}$ & & \begin{tabular}{l|l}
03 &. \\
83 &.
\end{tabular} & $\begin{array}{l}01 \\
93\end{array}$ & $\begin{array}{ll}-10 & .19 \\
.45 & .14\end{array}$. & $\begin{array}{l}.20 \\
.12\end{array}$ & $\begin{array}{l}.07 \\
.59\end{array}$ & $\begin{array}{l}-.04 \\
.75 \\
\end{array}$ & $\begin{array}{l}.10 \\
.45 \\
\end{array}$ & \begin{tabular}{|l|l|}
.04 & .57 \\
.78 & .00 \\
\end{tabular} & $\begin{array}{r}-.05 \\
.69\end{array}$ & 1 & & & & & \\
\hline D4 & .07 & .29 & & .02 & $\begin{array}{l}.26 \\
.04\end{array}$ & $\begin{array}{l}.27 \\
.03\end{array}$ & $\begin{array}{l}.20 \\
.11 \\
\end{array}$ & .41 & $\begin{array}{l}-.01 \\
.96\end{array}$ & $\begin{array}{l}.13 \\
.29 \\
\end{array}$ & $\begin{array}{l}.20 \\
.12\end{array}$ & & 41. & \begin{tabular}{l|}
51 \\
00
\end{tabular} & $\begin{array}{ll}.24 & .19 \\
.06 & .13\end{array}$ & $\begin{array}{l}.26 \\
.04\end{array}$ & $\begin{array}{l}.24 \\
.06 \\
\end{array}$ & $\begin{array}{l}.24 \\
.06 \\
\end{array}$ & $\begin{array}{l}.44 \\
.00\end{array}$ & $\begin{array}{ll}.29 & .23 \\
.02 & .07\end{array}$ & $\begin{array}{l}.33 \\
.01 \\
\end{array}$ & $\begin{array}{l}.27 \\
.03 \\
\end{array}$ & 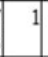 & & & & \\
\hline E1 & $\begin{array}{l}.14 \\
.28\end{array}$ & $.07=$ & $\begin{array}{l}19 \\
.15\end{array}$ & .05 & $\begin{array}{l}.04 \\
.76\end{array}$ & .13 & $\begin{array}{l}.07 \\
.58\end{array}$ & \begin{tabular}{|l|}
.30 \\
.02 \\
\end{tabular} & .71 & .27 & .47 & & $\begin{array}{lll}31 & . \\
01 & .\end{array}$ & $\begin{array}{l}27 \\
04 .\end{array}$ & \begin{tabular}{l|l|l}
.45 & .64 \\
.00 & .00 &. \\
\end{tabular} & .58 & $\begin{array}{l}.59 \\
.00\end{array}$ & $\begin{array}{l}.52 \\
.00\end{array}$ & $\begin{array}{l}.37 \\
.00\end{array}$ & $\mid \begin{array}{ll}.13 & .27 \\
.30 & .03\end{array}$ & $\begin{array}{l}.35 \\
.00\end{array}$ & $\begin{array}{l}.18 \\
.17\end{array}$ & $\begin{array}{l}.14 \\
.26\end{array}$ & 4 & & & \\
\hline E2 & $\begin{array}{l}.15 \\
.26\end{array}$ & .18 & & $\begin{array}{l}.19 \\
.13\end{array}$ & $\begin{array}{l}.34 \\
.01\end{array}$ & $\begin{array}{l}.15 \\
.25\end{array}$ & $\begin{array}{l}.04 \\
.77\end{array}$ & .40 & $\begin{array}{l}.27 \\
.03\end{array}$ & $\begin{array}{l}.01 \\
.92\end{array}$ & .43 & & 46. & $\begin{array}{l}57 \\
00\end{array}$ & $\begin{array}{ll}.27 & .11 \\
.04 & .39\end{array}$ & $\begin{array}{l}.22 \\
.08\end{array}$ & $\begin{array}{l}.18 \\
.16\end{array}$ & \begin{tabular}{|l|}
.27 \\
.03
\end{tabular} & $\begin{array}{l}.36 \\
.00\end{array}$ & \begin{tabular}{|ll}
.27 & .23 \\
.03 & .07 \\
\end{tabular} & \begin{tabular}{l|}
.13 \\
.32
\end{tabular} & $\begin{array}{l}.02 \\
.91\end{array}$ & $\begin{array}{l}.28 \\
.03\end{array}$ & $\begin{array}{l}.34 \\
.01\end{array}$ & & & \\
\hline E3 & \begin{tabular}{r|}
-.11 \\
.41 \\
\end{tabular} & .08 & & $\begin{array}{l}.15 \\
.27 \\
\end{array}$ & $\begin{array}{l}.19 \\
.15 \\
\end{array}$ & $\begin{array}{l}.09 \\
.51 \\
\end{array}$ & $\begin{array}{r}.05 \\
.70 \\
\end{array}$ & \begin{tabular}{|l|}
.04 \\
.76 \\
\end{tabular} & $\begin{array}{l}-.11 \\
.38 \\
\end{array}$ & $\begin{array}{r}-.12 \\
.37 \\
\end{array}$ & $\begin{array}{l}.07 \\
.60 \\
\end{array}$ & -.0 & 56 . & \begin{tabular}{l|}
12 \\
37 \\
\end{tabular} & $\begin{array}{ll}.09-10 \\
.51 & .43\end{array}$ & $\begin{array}{l}-.18 \\
.18 \\
\end{array}$ & $\begin{array}{l}.00 \\
.97 \\
\end{array}$ & \begin{tabular}{|l|}
.03 \\
.81 \\
\end{tabular} & $\begin{array}{r}.00 \\
1 \\
\end{array}$ & $\begin{array}{l}.14-.18 \\
.27 .17\end{array}$ & \begin{tabular}{|r|}
.11 \\
.41 \\
\end{tabular} & $\begin{array}{l}.38 \\
.00 \\
\end{array}$ & $\begin{array}{l}.07 \\
.59 \\
\end{array}$ & $\begin{array}{l}-.22 \\
.09 \\
\end{array}$ & $\begin{array}{l}-17 \\
20 \\
\end{array}$ & & \\
\hline E4 & $\begin{array}{l}.22 \\
.09 \\
\end{array}$ & & & & & $\begin{array}{l}.18 \\
.16 \\
\end{array}$ & $\begin{array}{r}-.06 \\
.66 \\
\end{array}$ & $\begin{array}{l}.23 \\
.08 \\
\end{array}$ & $\begin{array}{l}.04 \\
.77\end{array}$ & .51 & $\begin{array}{l}.16 \\
.23\end{array}$ & & & & $\begin{array}{l}.12-.10- \\
.35 .44\end{array}$ & -.10 & -.07 & $\begin{array}{l}.05 \\
.73\end{array}$ & $\begin{array}{r}.01 \\
.91 \\
\end{array}$ & $\mid \begin{array}{cc}.08 & .04 \\
.56 & .77\end{array}$ & $\begin{array}{r}.02 \\
.88\end{array}$ & $\begin{array}{r}-.16 \\
.24 \\
\end{array}$ & & & 9 & $\begin{array}{l}.63 \\
.00 \\
\end{array}$ & \\
\hline
\end{tabular}

Figure 4. Correlation matrix for Time 2 (measurement name index same as Figure 2). 


\begin{tabular}{|c|c|c|c|c|c|c|c|c|c|c|c|c|c|c|c|c|c|c|c|c|c|c|c|c|c|c|}
\hline A1 1 A & $\mathrm{A} 2$ & 13 & A4. & A5 B 1 & B2 1 & B3 1 & B4 $\mathrm{E}$ & B5 & B6 1 & \begin{tabular}{l|l} 
B7 & $\mathrm{E}$
\end{tabular} & B8 & B9 C & $\mathrm{C} 1$ & $\mathrm{C} 2$ & $\mathrm{C} 3 \mathrm{C}$ & $\mathrm{C} 4 \mathrm{C}$ & C5 $\mathrm{C}$ & C6 $\mathrm{D}$ & \begin{tabular}{l|l}
$\mathrm{D} 1$ & $\mathrm{D}$
\end{tabular} & \begin{tabular}{l|l}
$\mathrm{D} 2$ & $\mathrm{D}$ \\
\end{tabular} & D3 1 & \begin{tabular}{l|l}
$\mathrm{D} 4$ & $\mathrm{E}$ \\
\end{tabular} & \begin{tabular}{|l|l}
$E$ & $\mathrm{E}$ \\
\end{tabular} & E2 & \begin{tabular}{l|l} 
E3 & E
\end{tabular} & E4 \\
\hline $\begin{array}{ll}\text { A1 } & 1\end{array}$ & & & & & & & & & & & & & & & & & & & & & & & & & & \\
\hline \begin{tabular}{ll|}
$\mathrm{A} 2$ & .11 \\
& .34 \\
\end{tabular} & & & & & & & & & & & & & & & & & & & & & & & & & & \\
\hline $\begin{array}{rr}-.22 \\
.06\end{array}$ & $\begin{array}{l}15 \\
.19\end{array}$ & 1 & & & & & & & & & & & & & & & & & agnitu & tude & $\frac{\geq 0.5}{>0.4}$ & & & & & \\
\hline $\begin{array}{ll}4 & .39 \\
& .00 \\
\end{array}$ & .26. & & 1 & & & & & & & & & & & & & & & & & & & & & & & \\
\hline $\begin{array}{ll}\text { A5 } & .34 \\
& .00\end{array}$ & .26. & $\begin{array}{l}16 . \\
16 .\end{array}$ & .60 & 1 & & & & & & & & & & & & & & & & & & & & & & \\
\hline B1 $\left[\begin{array}{l}.52 \\
.00\end{array}\right.$. & .00 & & .55 & $\begin{array}{ll}.45 & 1 \\
.00 & \\
\end{array}$ & & & & & & & & & & & & & & & & & & & & & & \\
\hline $\begin{array}{rr}\text { B2 } & .08 \\
.48\end{array}$ & & & $\begin{array}{l}.07 \\
.57\end{array}$ & $\begin{array}{ll}.07 & .12 \\
.53 & .28\end{array}$ & 1 & & & & & & & & & & & & & & & & & & & & & \\
\hline $\begin{array}{ll}\text { B3 } & .26 \\
& 03\end{array}$ & & & $\begin{array}{l}17 \\
16\end{array}$ & $\begin{array}{l}.21 \\
.08 \\
.19\end{array}$ & & 1 & & & & & & & & & & & & & & & & & & & & \\
\hline $\begin{array}{lr}4 & .02 \\
& .86\end{array}$ & & & $\begin{array}{l}.03 \\
.84\end{array}$ & 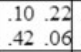 & $\begin{array}{l}.02 \\
.85 \\
\end{array}$ & & 1 & & & & & & & & & & & & & & & & & & & \\
\hline $\begin{array}{rr}\text { B5 } & 19 \\
.11\end{array}$ & & & $\begin{array}{l}15 \\
21\end{array}$ & $\begin{array}{r}-16-15 \\
.17 .19\end{array}$ & & $\begin{array}{r}.05 \\
.68 \\
\end{array}$ & $\begin{array}{l}.16 \\
.17 \\
\end{array}$ & 1 & & & & & & & & & & & & & & & & & & \\
\hline $\begin{array}{lr}\text { B6 } & .05 \\
& .68 \\
\end{array}$ & & & $\begin{array}{l}13 \\
30\end{array}$ & $\begin{array}{l}.19 .10 \\
.12 .41\end{array}$ & $\begin{array}{l}.02 \\
.86 \\
\end{array}$ & .65 & .65 & $\begin{array}{l}.09 \\
.45 \\
\end{array}$ & 1 & & & & & & & & & & & & & & & & & \\
\hline $\begin{array}{rr}\text { B7 } & .03 \\
& 80\end{array}$ & & \begin{tabular}{l|l}
13 & . \\
29 & .
\end{tabular} & $\begin{array}{l}20 \\
.09\end{array}$ & 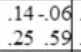 & $\begin{array}{l}.25 \\
.03 \\
\end{array}$ & .56 & $\begin{array}{l}.18 \\
.12\end{array}$ & .17. & .53 & 1 & & & & & & & & & & & & & & & & \\
\hline $\begin{array}{ll}\text { B8 } & .22 \\
& .07\end{array}$ & & & $\begin{array}{l}21 \\
08 \\
\end{array}$ & $\begin{array}{ll}.30 & .18 \\
.01 & .12 \\
\end{array}$ & $\begin{array}{l}.13 \\
.27 \\
\end{array}$ & .81 & $\begin{array}{l}31 \\
.01\end{array}$ & $\begin{array}{l}.02 \\
.89\end{array}$ & $\begin{array}{l}.51 \\
.00\end{array}$ & .60 & 1 & & & & & & & & & & & & & & & \\
\hline B9 $\begin{array}{r}15 \\
\\
.20\end{array}$ & & & .01 & $\begin{array}{lll}.01 & .19 \\
.94 & .11\end{array}$ & & $\begin{array}{l}.52 \\
.00 \\
\end{array}$ & $\begin{array}{l}.50 \\
.00\end{array}$ & $\begin{array}{r}.28 \\
.02\end{array}$ & .45 & .51. & $\begin{array}{l}.51 \\
.00\end{array}$ & 1 & & & & & & & & & & & & & & \\
\hline $\begin{array}{rr}-10 \\
43\end{array}$ & .059 & & $\begin{array}{l}12 \\
.34\end{array}$ & $\begin{array}{ll}.04 & .05 \\
.76 & .67\end{array}$ & .04 & $\begin{array}{l}.38 \\
.00\end{array}$ & $\begin{array}{l}.74 \\
.00\end{array}$ & $\begin{array}{l}26 \\
.03\end{array}$ & .60 & $\begin{array}{l}.18 \\
.13\end{array}$ & $\begin{array}{l}.23 \\
.05\end{array}$ & $\begin{array}{l}.48 \\
.00\end{array}$ & 1 & & & & & & & & & & & & & \\
\hline $\begin{array}{rr}C 2 & .03 \\
.80\end{array}$ & & \begin{tabular}{l|l}
05 & . \\
70 & .
\end{tabular} & $\begin{array}{l}.09 \\
.44\end{array}$ & $\begin{array}{lll}.08 & .03 \\
.50 & .84\end{array}$ & & .44 & .62. & .45 & $\begin{array}{l}.64 \\
.00\end{array}$ & $\begin{array}{l}30 \\
.01\end{array}$ & $\begin{array}{l}.36 \\
.00\end{array}$ & .46. & $\begin{array}{l}.83 \\
.00\end{array}$ & 1 & & & & & & & & & & & & \\
\hline $\begin{array}{rr}\text { C3 } & .06 \\
& .63\end{array}$ & & & $\begin{array}{l}10 \\
41\end{array}$ & 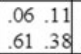 & $\begin{array}{l}.20 \\
.09\end{array}$ & $\begin{array}{l}.41 \\
.00\end{array}$ & $\begin{array}{l}.70 \\
.00\end{array}$ & .44 & $\begin{array}{l}.62 \\
.00\end{array}$ & $\begin{array}{l}.27 \\
.02\end{array}$ & $\begin{array}{l}.30 \\
.01\end{array}$ & .50 & $\begin{array}{l}.84 \\
.00\end{array}$ & $\begin{array}{l}.85 \\
.00\end{array}$ & 1 & & & & & & & & & & & \\
\hline $\begin{array}{ll}\mathrm{C} & .09 \\
& 44\end{array}$ & & $\begin{array}{l}04 \\
73\end{array}$. & $\begin{array}{l}.08 \\
50\end{array}$ & $\begin{array}{lll}.06 & .07 \\
.63 & .57\end{array}$ & \begin{tabular}{l|}
.21 \\
.08 \\
\end{tabular} & $\begin{array}{l}.51 \\
.00 \\
\end{array}$ & $\begin{array}{l}.54 \\
.00 \\
\end{array}$ & $\begin{array}{l}.26 \\
.03 \\
\end{array}$ & & .49 & & .48. & $\begin{array}{l}.66 \\
.00 \\
\end{array}$ & & .66 & 1 & & & & & & & & & & \\
\hline $\begin{array}{lr}\text { C5 } & .04 \\
& .77\end{array}$ & & \begin{tabular}{l|l}
10 & . \\
42 & .
\end{tabular} & $\begin{array}{l}15 \\
22\end{array}$ & $\begin{array}{ll}.40 & .15 \\
.00 & .21\end{array}$ & $\begin{array}{l}.10 \\
.41\end{array}$ & $\begin{array}{l}.55 \\
.00\end{array}$ & $\begin{array}{l}.46 \\
.00\end{array}$ & & .62 & .40. & & \begin{tabular}{l|l}
.33 \\
.01
\end{tabular}. & $\begin{array}{l}.57 \\
.00\end{array}$ & .52 & .04. & $\begin{array}{l}.66 \\
.00\end{array}$ & 1 & & & & & & & & & \\
\hline $\begin{array}{ll}\text { C6 } & .08 \\
& 49\end{array}$ & & \begin{tabular}{l|l}
13 & \\
28 &.
\end{tabular} & $\begin{array}{l}.37 \\
.00 \\
\end{array}$ & $\begin{array}{lll}.30 & .12 \\
.01 & .31\end{array}$ & $\begin{array}{l}.07 \\
.58 \\
\end{array}$ & $\begin{array}{l}.35 \\
.00 \\
\end{array}$ & $\begin{array}{l}.09 \\
47\end{array}$ & .04. & $\begin{array}{l}.48 \\
.00\end{array}$ & $\begin{array}{l}37 \\
.00\end{array}$ & $\begin{array}{l}.33 \\
.00 \\
\end{array}$ & $\begin{array}{l}.27 \\
.02\end{array}$ & $\begin{array}{l}.17 \\
.14\end{array}$ & $\begin{array}{l}.22 \\
.06\end{array}$ & $\begin{array}{l}.18 \\
.13\end{array}$ & $\begin{array}{l}.33 \\
.00\end{array}$ & .42 & 1 & & & & & & & & \\
\hline $\begin{array}{ll}\text { D1 } & .00 \\
& \\
& 1 .\end{array}$ & .09 & \begin{tabular}{l|l}
01 & . \\
95 & .
\end{tabular} & $\begin{array}{l}.01 \\
.93\end{array}$ & $\begin{array}{ll}.13 & .25 \\
.30 & .03\end{array}$ & $\begin{array}{l}.33 \\
.01\end{array}$ & $\begin{array}{l}.03 \\
.78\end{array}$ & $\begin{array}{l}.16 \\
.16\end{array}$ & $\begin{array}{l}.31 \\
.01\end{array}$ & $\begin{array}{l}.09 \\
.46\end{array}$ & .00. & $\begin{array}{l}.03 \\
.78\end{array}$ & $\begin{array}{l}.16 \\
.18\end{array}$ & $\begin{array}{l}.12 \\
.30\end{array}$ & $\begin{array}{l}.24 \\
.05\end{array}$ & $\begin{array}{l}.20 \\
.09\end{array}$ & $\begin{array}{l}.00 \\
.98\end{array}$ & .03 & $\begin{array}{l}.14 \\
.25\end{array}$ & 1 & & & & & & & \\
\hline $\begin{array}{rr}\text { D2 } & .04 \\
& .77 \\
\end{array}$ & .09. & $\begin{array}{l}16 . \\
18\end{array}$ & $\begin{array}{l}.04 \\
.72\end{array}$ & $\begin{array}{ll}.26 & .06 \\
.03 & .62\end{array}$ & $\begin{array}{l}.20 \\
.08 \\
\end{array}$ & $\begin{array}{l}.35 \\
.00\end{array}$ & $.36-$ & $\begin{array}{r}.07 \\
.55 \\
\end{array}$ & $\begin{array}{l}.29 \\
.01\end{array}$ & $\begin{array}{l}19 \\
.12\end{array}$ & $\begin{array}{l}.27 \\
.02\end{array}$ & $\begin{array}{l}.14 \\
.22 \\
\end{array}$ & $\begin{array}{l}30 \\
.00\end{array}$ & $\begin{array}{l}.37 \\
.00\end{array}$ & \begin{tabular}{l|l}
.32 & \\
.01 &
\end{tabular} & $\begin{array}{l}.21 \\
.07\end{array}$ & .50 & $\begin{array}{l}17 \\
15\end{array}$ & $\begin{array}{l}.14 \\
.25\end{array}$ & 1 & & & & & & \\
\hline $\begin{array}{rr}\text { D3 } & .06 \\
& .64\end{array}$ & .22. & $\begin{array}{l}04 \\
77\end{array}$. & .06 & $\begin{array}{ll}.08 & .27 \\
.50 & .02\end{array}$ & $\begin{array}{l}.33 \\
.01 \\
\end{array}$ & $\begin{array}{l}.06 \\
.59\end{array}$ & \begin{tabular}{l|l}
.18 \\
.14
\end{tabular} & $\begin{array}{l}.31 \\
.01 \\
\end{array}$ & $\begin{array}{l}.14 \\
.23\end{array}$ & .00. & .02 & $\begin{array}{r}.10 \\
.41\end{array}$ & $\begin{array}{l}.13 \\
.29\end{array}$ & $\begin{array}{l}.24 \\
.04\end{array}$ & $\begin{array}{l}.19 \\
.11\end{array}$ & $\begin{array}{l}.09 \\
.47\end{array}$ & .15 & \begin{tabular}{l|l}
.03 &. \\
.78 &
\end{tabular} & \begin{tabular}{l|l}
.61 \\
.00
\end{tabular} & $\begin{array}{l}.10 \\
.40\end{array}$ & 1 & & & & & \\
\hline $\begin{array}{ll}\text { D4 } & .08 \\
& .50 \\
\end{array}$ & $\begin{array}{ll}.15 & \\
21 & \end{array}$ & & $\begin{array}{l}22 \\
.07 \\
\end{array}$ & $\begin{array}{ll}.32 & .26 \\
.01 & .02 \\
\end{array}$ & .01. & .49 & $\begin{array}{l}17 \\
.16 \\
\end{array}$ & $\begin{array}{l}.16 \\
.18 \\
\end{array}$ & $\begin{array}{l}.37 \\
.00 \\
\end{array}$ & .44 . & .46 & $\begin{array}{l}.36 \\
.00 \\
\end{array}$ & $\begin{array}{l}.27 \\
.02 \\
\end{array}$ & $\begin{array}{l}.36 \\
.00 \\
\end{array}$ & $\begin{array}{l}.31 \\
.01\end{array}$ & $\begin{array}{l}.36 \\
.00 \\
\end{array}$ & .48 . & .40 & .14 & $\begin{array}{l}39 \\
.00\end{array}$ & $\begin{array}{l}.16 \\
.18 \\
\end{array}$ & 1 & & & & \\
\hline $\begin{array}{ll}\text { E1 } & .05 \\
& .66\end{array}$ & $\begin{array}{l}01 \\
91\end{array}$ & & $\begin{array}{l}.09 \\
.47\end{array}$ & $\begin{array}{ll}19 & 11 \\
.12 & .35\end{array}$ & $\begin{array}{l}.08 \\
.50 \\
\end{array}$ & .44 & $\begin{array}{l}.75 \\
.00\end{array}$ & $\begin{array}{l}.18 \\
.12\end{array}$ & $\begin{array}{l}.62 \\
.00\end{array}$ & $\begin{array}{l}.35 \\
.00\end{array}$ & $\begin{array}{l}.31 \\
.01\end{array}$ & $\begin{array}{l}.50 \\
.00\end{array}$ & $\begin{array}{l}.71 \\
.00\end{array}$ & .66 & .68 . & $\begin{array}{l}.54 \\
.00\end{array}$ & .50 & $\begin{array}{l}25 \\
.03\end{array}$ & $\begin{array}{l}.23 \\
.05\end{array}$ & .44. & \begin{tabular}{l|l}
.17 \\
.15
\end{tabular} & $\begin{array}{l}.27 \\
.02\end{array}$ & 1 & & & \\
\hline $\begin{array}{rr}\text { E2 } & .08 \\
& .49\end{array}$ & .02. & $\begin{array}{l}06 \\
64 .\end{array}$ & $\begin{array}{l}15 \\
22 \\
\end{array}$ & $\begin{array}{ll}28 & .03 \\
.02 & .78 \\
\end{array}$ & $\begin{array}{l}.02 \\
.86 \\
\end{array}$ & \begin{tabular}{|l|}
.61 \\
.00 \\
\end{tabular} & $\begin{array}{l}.31 \\
.01 \\
\end{array}$ & $\begin{array}{r}.13 \\
.28\end{array}$ & $\begin{array}{l}.49 \\
.00 \\
\end{array}$ & $\begin{array}{l}.57 \\
.00\end{array}$ & .56 & $\begin{array}{l}.35 \\
.00 \\
\end{array}$ & .22 & $\begin{array}{l}.24 \\
.04 \\
\end{array}$ & $\begin{array}{l}.21 \\
.07\end{array}$ & $\begin{array}{l}.32 \\
.01\end{array}$ & .00 & \begin{tabular}{l|l}
.37 \\
.00
\end{tabular} & .05 & .00. & .06. & & .41 & 1 & & \\
\hline $\begin{array}{rr}-10 \\
40 .\end{array}$ & $\begin{array}{l}15 \\
21\end{array}$ & $\begin{array}{l}15 \\
22\end{array}$ & $\begin{array}{l}15 \\
23\end{array}$ & $\begin{array}{lll}.09 & .00 \\
.45 & .99\end{array}$ & .09 & $\begin{array}{l}.31 \\
.01\end{array}$ & $\begin{array}{r}-.08 \\
.53\end{array}$ & $\begin{array}{r}.20 \\
.10\end{array}$ & $\begin{array}{r}.13 \\
.27\end{array}$ & $\begin{array}{r}.08 \\
.51\end{array}$ & $\begin{array}{l}.30 \\
.01\end{array}$ & $\begin{array}{r}-.05 \\
.68\end{array}$ & $\begin{array}{r}-02 \\
.87\end{array}$ & $\begin{array}{r}-20 \\
.10\end{array}$ & \begin{tabular}{l|l}
-18 \\
.14
\end{tabular} & $\begin{array}{l}.20 \\
.09\end{array}$ & $\begin{array}{l}13 \\
.30\end{array}$ & \begin{tabular}{r|}
.01 \\
.91
\end{tabular} & $.11-$ & 74 . & 31 & $\begin{array}{l}02 \\
84\end{array}$ & .04. & .07 & 1 & \\
\hline .06. & 21. & $\begin{array}{l}16 \\
21\end{array}$ & $\begin{array}{l}.24 \\
06\end{array}$ & $\begin{array}{ll}.22 & .06 \\
.07 & .61\end{array}$ & $\begin{array}{r}-15 \\
-23\end{array}$ & $\begin{array}{l}.09 \\
44\end{array}$ & $.00-$ & & $\begin{array}{r}-05 \\
68\end{array}$ & $\begin{array}{r}.05 \\
66\end{array}$ & & $\begin{array}{r}-.01 \\
93\end{array}$ & .07 & $\begin{array}{r}-04 \\
.77\end{array}$ & \begin{tabular}{r|}
-08 \\
-52
\end{tabular} & $\begin{array}{l}.20 \\
.09\end{array}$ & .03 & & .04. & & $\begin{array}{l}.01 \\
93\end{array}$ & \begin{tabular}{l|l}
11 \\
39 \\
39
\end{tabular} & \begin{tabular}{l|l}
03 &. \\
82 &.
\end{tabular} & & .75 & 1 \\
\hline
\end{tabular}

Figure 5. Correlation matrix for Time 3 (measurement name index same as Figure 2).

numbers of relationships among the motivational factors during time 1, both within and across groups of factors: individual differences - predictive (A), individual differences - motivations (B), the perceptions of the course climate and content $(\mathrm{C})$, perceptions of $\mathrm{ME}$. These relationships weakened as the course progressed. During Time 2, many of these relationships diminished, especially direct relationships between stable characteristics (A) and malleable characteristics 
(B and C). These relationships converged further from Time 2 to Time 3. Many of the motivational characteristics in categories of individual differences - motivational (B), and perceptions of course climate and content (C) were initially highly correlated with each other. In most instances, these correlations remained stable throughout the course, including: self-efficacy for career in $\mathrm{ME}$, learning and future goals, value, relevance, and utility. Self-efficacy for course was highly correlated with many factors during Time 1 and Time 3, less so at Time 2 (Figures 3, 5, and 6). Correlation between perceived climate - professor (C4) and other motivational characteristics (learning and future goals (B4), self-efficacy for course (B6), engagement and effort in course (B7), value (C1), relevance $(\mathrm{C} 2)$, and utility $(\mathrm{C} 3)$ ) remained high and stable throughout the course.

Identifying these correlational patterns and their stability over time provides a set of core components characterizing these ME students' motivational profile for ME design, including how sensitive they are to skill development and social experiences. Future research may reveal more clarity and nuances in why these observed patterns occur, and how generalizable they are for $\mathrm{ME}$ and across engineering disciplines.

\section{Discussion}

This study demonstrated a number of unique findings regarding engineering students' motivational profiles, related to their learning and identity development. Students' motivational profiles consisted of a cluster of perceptual and experiential variables that were strongly correlated with motivational and learning outcomes (illustrated in Figures 2, 4, and 5). Tracking these factors (mapping multipoint trajectories-of-change data) demonstrated that they changed slightly but not significantly over time (Figure 3). As those patterns corresponded to perceptions of their professor and peer interactions, it appears that they were amenable to instructional intervention and responsive to social modeling. Some of these factors had been used before, generally in single-event, explanatory designs; this study took those relationships to the next level, using more variables than most previous studies, and also tracking their changes and changing relationships, presenting a more complete picture of these students' dynamic motivational profile.

This study also revealed a number of new relationships among factors not previously linked in the engineering education research. It demonstrated links between engineering students' perceptions of their field of study (e.g. requirements for math and science aptitude, degree of structure) and their own self-efficacy and success expectations for both the design course and their careers. This work also revealed what may prove to be important distinctions between engineering students' selfefficacy for, and engagement in, the course generally and team tasks more specifically. These newly revealed relationships offer opportunity to inform new strands of research in engineering education, and they hold promise for improving engineering instruction and the design of dynamic learning environments that support adaptive skill development and innovation. 
To develop adaptive skills and embrace innovation as future engineers, students need to be comfortable with ill-structured and open-ended problem-solving. These engineering students indicated a moderate preference for, and perceived competence in, more structured problems and known outcomes, along with high need for cognition and preference for interactive learning environments. Outside of design courses, more structured problems are the most common and familiar, from students' prior educational experiences. Foundational engineering courses need to help students become comfortable with ill-structured problems and develop competencies related to creativity and innovation. There were some decreases in student perceptions of value, relevance, and utility of course material as the course progressed, suggesting a gap between students' expectations of design and their experiences in a design course.

Based on the alignment of data points with the major course assignments, some of the design steps that required abstraction were less well received by students than those with very concrete elements. This finding identifies what further research may reveal to be a critical gap between current instruction and career demands for mechanical engineers with higher-order skills. The trajectory also demonstrated that some productive motivational characteristics adjusted during the time students were challenged to synthesize all of their prior knowledge and experience in the culminating design courses. When compared to traditional motivational models from school settings, these may be viewed as negative changes, but in fact they are patterns similar to those demonstrated by advanced students in other applied design disciplines. ${ }^{26}$ They are also similar to patterns found among engineering students ${ }^{13}$ and for teachers from other fields learning about engineering. ${ }^{28}$

Student responses to situational components for Time 1 had the highest values, with Time 2 the lowest. Very similar trends were noticed for utilization, value, and relevance for content and climate in the course. The students in the course had to write design reports documenting different steps of the design processes, which included analysis of customer requirements, functional analysis, generating ideas, and selection and analysis of ideas. The instructor of the course needs to emphasize the situational component of motivation for the course to ensure that students better understand course assignments and activities. Student responses indicated that the emotional components of motivation for the course remained stable throughout the semester. Principles of Design (AME 4163) was modified to explicitly address motivational features. The course was then evaluated based on motivational characteristics addressed in the SUCCESS framework, using questionnaires with subscales addressing those characteristics. Examining students' motivational profiles provided an opportunity to identify course motivational features. The collection of trajectory data provided information synchronized with the introduction of different course activities, as well as tracking patterns of overall change. Motivational features related to utilization can be improved, and features related to competence were addressed adequately but can still be improved further. The social aspect of motivation was particularly strong, especially in the team environment. Situational and 
systemic components of motivation need to be enhanced, such as through focus on integration of materials learned in previous courses.

In this work, progress has been made toward identifying key features of engineering students' productive (learning and engagement-related) motivational profiles. A set of frequently used motivation measures, recontextualized for engineering courses and programs, was tested. These measures demonstrated good evidence of reliability and validity for this purpose. The SUCCESS framework was applied to course redesign and to analysis of motivation strategies for engineering education, and the researchers developed engineering-specific strategies to illustrate its utility for the field.

\section{Acknowledgement}

The researchers on this project are grateful for technical assistance and support from the staff at the Center for Educational Development and Research (CEDaR) in the Jeannine Rainbolt College of Education, University of Oklahoma, Norman campus.

\section{Funding}

This research received no specific grant from any funding agency in the public, commercial, or not-for-profit sectors.

\section{Conflict of interest}

None declared.

\section{References}

1. Hardré PL. The Motivating Opportunities Model (MOM) for performance SUCCESS: Design, development and instructional implications. Perform Improv Quart 2009; 22: 5-26.

2. Dai DY and Sternberg RJ. Beyond cognitivism: toward an integrated understanding of intellectual functioning and development. In: Dai DY, Sternberg RJ (eds) Motivation, emotion and cognition: integrative perspectives on intellectual functioning and development. New York: Taylor \& Francis, 2004, pp.3-40.

3. Merriam SB, Caffarella RS and Baumgartner LM. Learning in adulthood: a comprehensive guide. New York: Wiley, 2006.

4. Brown JS, Collins A and Duguid P. Situated cognition and the culture of learning. Educ Res 1989; 18: 32-42.

5. Hardré PL. SUCCESS for teaching assistant professional development. J Appl Instruc Des 2012; 2: 50-56.

6. Blue CE, Blevins LG, Carriere P, et al. The Engineering workforce: Current state, issues, and recommendations. Final report to the assistant director of engineering. Arlington, VA: National Science Foundation, 2005.

7. Sheppard SD, Macatangay K, Colby A, et al. Educating engineers: designing for the future of the field. San Francisco: Jossey-Bass, 2009.

8. Lang JD, Cruse S, McVey FD, et al. Industry expectations of new engineers: a survey to assist curriculum designers. J Eng Educ 1998; 88: 43-51.

9. National Academy of Engineering. The engineer of 2020: visions of engineering in the new century. Washington, DC: National Academy of Engineering, 2004. 
10. National Academy of Engineering. Educating the engineer of 2020: adapting engineering education to the new century. Washington, DC: National Academy of Engineering, 2004.

11. Burtner $\mathbf{J}$. The use of discriminant analysis to investigate the influence of non-cognitive factors on engineering school persistence. J Eng Educ 2005; 94: 335-339.

12. Felder RM, Sheppard SD and Smith KA. A new journal for a field in transition. $J$ Eng Educ 2005; 94: 7-12.

13. Jones BD, Paretti MC, Hein SF, et al. An analysis of motivations constructs with FirstYear engineering students: relationships among expectancies, values, achievement, and career plans. J Eng Des 2010; 99: 319-336.

14. Grose TK. Staying on track: engineering schools used to shrug off high attrition rates. Now they're working to help students achieve early - and enduring success. Prism, http://www.prism-magazine.org (February 2008, accessed 14 December 2012).

15. Marra RM, Rodgers KA, Shen D, et al. Leaving engineering: a multi-year single institution study. J Eng Educ 2012; 17: 22-28.

16. Hoit $\mathrm{M}$ and Ohland $\mathrm{M}$. The impact of a discipline-based Introduction to Engineering course on improving retention. J Eng Educ 1998; 87: 79-85.

17. Kuh GD, Kinzie J, Buckley J, et al. What matters to student success: a review of the literature. National Symposium on Postsecondary Student Success, http://nces.ed.gov/ npec/pdf/Kuh_Team_ExecSumm.pdf (2006, accessed 12 December 2012).

18. Lent RW, Sheu HB, Singley D, et al. Longitudinal relations of self-efficacy to outcome expectations, interests, and major choice goals in engineering students. $J$ Vocat Behav 2008; 73: 328-335.

19. Carberry AR, Lee HS and Ohland MW. Measuring engineering design self-efficacy. J Eng Educ 2010; 99: 71-79.

20. Ponton MK, Edmister JH, Ukeiley LS, et al. Understanding the role of self-efficacy in engineering education. $J$ Eng Educ 2001; 90: 247-251.

21. Lent RW, Brown SD, Schmidt J, et al. Relation of contextual supports and barriers to choice behavior in engineering majors: test of alternative social cognitive models. $J$ Counsel Psychol 2003; 50: 458-465.

22. Jones BD, Epler CM, Mokri P, et al. The effects of a collaborative problembased learning experience on students' motivation in engineering capstone courses. Interdiscipl J Problem-based Learn 2013; 7. Doi.org/10.7771/1541-5015.1344.

23. Matusovich HM, Lee WC, Janeski JA, et al. How instructors and classroom climate contribute to the motivation of first-year engineering students. In: ASEE 2011 annual conference and exposition, Vancouver, BC, Canada, 26-29 June 2011. Washington, DC: American Society for Engineering Education.

24. Gasiewski JA, Eagan MK, Garcia GA, et al. From gatekeeping to engagement: a multicontextual, mixed method study of student academic engagement in introductory STEM courses. Res Higher Educ 2011; 53: 229-261.

25. Chi M. Two approaches to the study of experts' characteristics. In: Charness N, Feltovich P, Hoffman R (eds) Cambridge handbook of expertise and expert performance. Cambridge: Cambridge University Press, 2006, pp.21-30.

26. Nelson HG and Stolterman E. The design way: intentional change in an unpredictable world: foundations and fundamentals of design competence. Englewood Cliffs, NJ: Educational Technology Publications, 2003. 
27. Allan $\mathrm{M}$ and Chisholm C. Achieving engineering competencies in the global information society through the integration of on-campus and workplace environments. Ind Higher Educ 2008; 22: 145-152.

28. Bradford School of Technical Management. Managerial skills and expertise used by samples of engineers in Britain, Australia, Western Canada, Japan, the Netherlands and Norway. Bradford, UK: University of Bradford, 1984.

29. Earnest $\mathbf{J}$ and Hills S. ABET engineering technology criteria and competency-based engineering education. In: 35th ASEE/IEEE frontiers in education conference, Indianapolis, IN, 2005. Washington, DC: American Society for Engineering Education.

30. Evers FT, Rush JC and Berdrow I. The bases of competence: skills for lifelong learning and employability. San Francisco, CA: Jossey-Bass Publishers, 1998.

31. McLaughlin M. Employability skills profile: what are employers looking for? Ottawa, ON: Conference Board of Canada, 1992.

32. Sparkes JJ. Quality in engineering education. Int J Continuing Eng Educ Life-Long Learn 1990; 1: 18-32.

33. Radcliffe DF. Innovation as a meta graduate attribute for engineers. Int $J$ Eng Educ 2005; 21: 194-199.

34. Wulf WA and Fisher GMC. A makeover for engineering education. Sci Technol 2002; 18: 35 .

35. Business Roundtable. Tapping America's potential: the education for innovation initiative. Washington, DC: Business Roundtable, 2005.

36. Christensen CM. The innovator's dilemma: the revolutionary book that will change the way you do business. New York: Harper Business Press, 2011.

37. Dai DY. Design research on learning and thinking in educational settings: enhancing intellectual growth and functioning. New York: Routledge, 2012.

38. Bereiter C and Scardamalia M. Surpassing ourselves: an inquiry into the nature and implications of expertise. Chicago: Open Court Publishing Company, 1993.

39. Brown A and Green TD. The essentials of instructional design. New York: Pearson, 2006.

40. Lave J and Wenger E. Situated learning: legitimate peripheral participation. New York: Cambridge University Press, 1991.

41. Lawson B. How designers think: the design process demystified. Burlington, MA: Elsevier, 1997.

42. Lawson B and Dorst K. Design expertise. Burlington, MA: Elsevier, 2009.

43. Chubin DE, May GS and Babco EL. Diversifying the engineering workforce. $J$ Eng Educ 2005; 94: 73-86.

44. Hardré P and Reeve J. A motivational model of rural students' intentions to persist in, versus drop out of, high school. J Educ Psychol 2003; 95: 347-356.

45. Hardré PL, Ge X and Thomas M. An investigation of the development of instructional design expertise. Perform Improv Quart 2007; 19: 55-82.

46. Hardré PL and Kollmann SL. Dynamics of instructional and perceptual factors in ID competence development. J Learn Des 2013; 6: 34-48.

47. Hardré PL, Ling C, Shehab RL, et al. Teachers in an interdisciplinary learning community: engaging, integrating and strengthening K-12 education. J Teacher Educ 2003; 64: 410-426.

48. Bransford JD, Brown AL and Cocking RR. How people learn: brain, mind, experience and school. Washington, DC: National Research Council, 1999. 
49. Huber MT and Hutchings P. The advancement of learning: building the teaching commons. San Francisco, CA: Jossey-Bass, 2005.

50. Laster MT. Teach the way the brain learns. New York: Rowman \& Littlefield, 2009.

51. Cross N. Designerly ways of knowing. Basel, Switzerland: Birkhäuser Verlag, AG, 2007.

52. Fox MA and Hackerman N. Evaluating and improving undergraduate teaching in science, technology, engineering and mathematics. Washington, DC: National Academies Press, 2003.

53. Hardré PL and Burris A. What contributes to TA development: differential responses to key design features. Instruc Sci 2012; 40: 93-118.

54. McCray RA, DeHaan R, Kasper MA, et al. Improving undergraduate instruction in science, technology, engineering and mathematics. Washington, DC: National Academies Press, 2003.

55. National Science Foundation. Invention and impact: building excellence in undergraduate science, technology, engineering and mathematics (STEM) education. Washington, DC: American Association for the Advancement of Science, 2004.

56. Hardré P. Beyond two decades of motivation: a review of the research and practice in human performance technology. Hum Resource Dev Rev 2003; 2: 54-81.

57. Hardré PL. Motivating math learning for rural students: teacher and student perspectives. Math Educ Res J 2011; 23: 213-233.

58. Hardré PL and Miller RB. Toward a current, comprehensive, integrative, and flexible model of motivation for instructional design. Perform Improv Quart 2006; 19: 25-52.

59. Cohen AR, Stotland E and Wolfe DM. An experimental investigation of need for cognition. J Abnorm Social Psychol 1955; 51: 291-294.

60. Atkinson $\mathrm{J}$ and Raynor JO. Personality, motivation and achievement. Oxford, UK: Hemisphere Pub. Corp., 1978.

61. Cacioppo JT, Petty RE and Kao CF. The efficient assessment of need for cognition. J Pers Assess 1984; 48: 306-307.

62. Hardré PL, Crowson HM and Xie K. Differential effects of web-based and paper-based administration of questionnaire research instruments in authentic contexts-of-use. J Educ Comput Res 2010; 42: 103-133.

63. Besterfield-Sacre M, Shuman L, Hoare R, et al. University of Pittsburgh School of Engineering student assessment system. Pittsburgh, PA: University of Pittsburgh, 2005, pp.1-54.

64. Neuberg SL and Newsom JT. Personal need for structure: individual differences in the desire for simple structure. J Pers Soc Psychol 1993; 65: 113-131.

65. Deci EL, Eghrari H, Patrick BC, et al. Facilitating internalization: the self-determination theory perspective. J Pers 1994; 62: 119-142.

66. Ryan RM and Connell JP. Perceived locus of causality and internalization: examining reasons for acting in two domains. J Pers Soc Psychol 1989; 57: 749-761.

67. Evans AN. Using basic statistics in the behavioral and social sciences, 5th ed. Thousands Oks, CA: Sage Publications, 2014. 